\title{
CONTROLLING FACTORS ON THE ABUNDANCE, DIVERSITY AND SIZE OF LIVING BENTHIC FORAMINIFERA IN THE NE SECTOR OF GUANABARA BAY (BRAZIL)
}

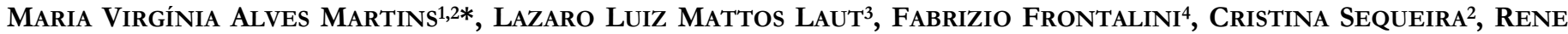 \\ Rodrigues $^{1}$, Maria Clara Machado da Fonseca ${ }^{5}$, Sergio Bergamaschi, ${ }^{1}$, Eberto Pereira ${ }^{1}$, Francielli Paula \\ Delavy $^{6}$, Alberto Garcia Figueiredo Jr. ${ }^{7}$, Paulo Miranda ${ }^{2}$, Denise Terroso ${ }^{2}$, Assane Luís Pena ${ }^{8}$, Vanessa Mattos \\ LAUT $^{9}$, RUBENS FIGUEIRA ${ }^{10}$ AND FERNANDO ROCHA ${ }^{2}$
}

1 Universidade do Estado do Rio de Janeiro, Faculdade de Geologia, Departamento de Estratigrafia e Paleontologia. Av. São Francisco Xavier, 524, sala 2020A, Maracanã. 20550-013 Rio de Janeiro, RJ, Brazil. virginia.martins@ua.pt, rene@uerj.br, sergioberg7@hotmail.com, egbertogeologia@gmail.com

2 Universidade de Aveiro, GeoBioTec, Departamento de Geociências, Campus de Santiago, 3810-193 Aveiro, Portugal. csequeira@ua.pt, pfnmiranda@gmail.com, laraterroso@ua.pt, tavares.rocha@ua.pt

3 Universidade Federal do Estado do Rio de Janeiro - UNIRIO, Laboratório de Micropaleontologia - LabMicro, Av. Pasteur, 458, IBIO/CCET sala 500 Urca, 22.240-490, Rio de Janeiro, Brazil. lazarolaut@hotmail.com

4 Università degli Studi di Urbino "Carlo Bo", Dipartimento di Scienze Pure e Applicate (DiSPeA) Urbino, Italy. fabrizio.frontalini@uniurb.it

5 Undergraduate student, Laboratório de Micropaleontologia, Universidade do Estado do Rio de Janeiro (LMP-UERJ), Faculdade de Geologia, Departamento de Estratigrafia e Paleontologia. Av. São Francisco Xavier, 524, sala 4037F, Maracanã. 20550-013 Rio de Janeiro, RJ, Brazil. geomariaclara@gmail.com

6 Programa de Capacitação Institucional, Museu Paraense Emílio Goeldi, Coordenação de Botânica. Av. Perimetral, Terra Firme, CEP 66077-830, Belém, PA, Brazil. delavy7@gmail.com

7 Universidade Federal Fluminense, Departamento de Geologia, Lagemar. Av. Milton Tavares de Souza, s/n, CEP 24210-340, Niterói, RJ, Brazil. afigueiredo@id.uff.br

8 Universidade Pedagógica - Moçambique, Departamento de Ciências Naturais e Matemática. Rua D. Francisco de Almeida $2^{\circ}$ Bairro, Ponta-Gêa, 737/751 - Beira - Mozambique - Caixa-postal: 2025. assanpena@gmail.com

9 Programa de Pós-Graduação em Biologia Marinha e Ecossistemas Costeiros, Universidade Federal Fluminense - UFF. Outeiro São João Batista, s/nº - Niterói - RJ, Brazil. CEP 24001-970. vanessalaut@hotmail.com

10 Departamento de Oceanografia Física, Instituto Oceanográfico, Universidade de São Paulo, Brazil. rfigueira@usp.br

*Corresponding Author, virginia.martins@ua.pt

Received on 30 October 2016

Received in revised form on 1 December 2016

Accepted on 5 December 2016

Editor:

Maria Antonieta da Conceição Rodrigues, Universidade do Estado do Rio de Janeiro, Brazil
Citation:

Martins, M.V.A., Laut, L.L.M., Frontalini, F., Sequeira, C., Rodrigues, R., Fonseca, M.C.F., Bergamaschi, S., Pereira, E., Delavy, F.P., Figueiredo Jr., A.G., Miranda, P., Terroso, D., Pena, A.L., Laut, V.M., Figueira, R., Rocha.F., 2016. Controlling factors on the abundance, diversity and size of living benthic foraminifera in the NE sector of Guanabara Bay (Brazil). Journal of Sedimentary Environments, 1(4): 393-410

\begin{abstract}
The disposal of waste and sewage by anthropic activities in Guanabara Bay (GB), Rio de Janeiro State (Brazil) is negatively affected this coastal ecosystem over the last few decades. This research intends to document how organic
\end{abstract}

matter and metal enrichment affect the benthic organisms. Physicochemical, textural, geochemical and microfaunal data (foraminifera) are analyzed in nine stations in the NE sector of Guanabara Bay. The size and structure of the living 
foraminiferal assemblages are analyzed on each sedimentary fractions $(63-150 \mu \mathrm{m}, 150-250 \mu \mathrm{m}, 250-500 \mu \mathrm{m}$ and $>500$ $\mu \mathrm{m})$ of every station. In the fraction $>500 \mu \mathrm{m}$ no foraminifera were found. Results suggest that organic matter contents are high everywhere whereas metals concentrations increase in São Gonçalo region. The dimension, diversity and equitability of the living foraminiferal assemblages were reduced in the study area. Ammonia tepida was the dominant taxon in all samples. Living specimens identified in the 63$150 \mu \mathrm{m}$ sedimentary fraction were found at all stations except in front of São Gonçalo city (stations GB9 and GB8). Most of species were not found in the $250-500 \mu \mathrm{m}$ sediment

\section{Introduction}

Guanabara Bay (GB) is located at latitude $22^{\circ} 40^{\prime}$ and $23^{\circ} 00^{\prime} \mathrm{S}$ and longitude $43^{\circ} 00^{\prime}$ and $43^{\circ} 20^{\prime} \mathrm{W}$, in Rio de Janeiro State (Brazil). It has $131 \mathrm{~km}$ of perimeter and approximately occupies an area of $\sim 384 \mathrm{~km}^{2}$ (Guimarães and Mello, 2006). It has maximum north-south length of $\sim 28 \mathrm{~km}$ from the Copacabana tip to the Magé River mouth and an east-west length of $\sim 30 \mathrm{~km}$ between the Meriti and Guapimirim Rivers (Kjerfve et al., 1997).

Nowadays about 11 million people live around GB basin and negatively affect this ecosystem. In addition, GB is located in the second greater industrialization area of Brazil, which has also significantly contributed to its environmental degradation (Baptista Neto et al., 2006). Deforestation, rivers rectification, release of about 8 million of domestic untreated sewage, maritime terminals, ports, refineries and shipyards are among the human activities that mostly contribute to the environmental degradation of GB (Vilela et al., 2014). Because of this, GB was identified as one of the most polluted coastal environments in Brazilian coastline (e.g., Rebello et al., 1986; Vandenberg and Rebello, 1986; Leal and Wagener 1993; Barrocas and Wasserman, 1995; Perin et al., 1997; Baptista Neto et al. 2000, 2005, 2006; Faria and Sanchez, 2001; Covelli et al., 2012; Donnici et al., 2012; Cordeiro et al., 2015). The effects of pollution on organisms living in this environment are still poorly understood.

Foraminifera have been widely recognized for their importance as bioindicators of environmental conditions (Alve, 1995; Armynot du Châtelet and Debenay, 2010; Frontalini and Coccioni, 2011; Schönfeld et al., 2012 for review) and have been therefore used in environmental impact studies (e.g. Frontalini et al., 2009; Martins et al. 2015; 2016 a, b; Laut et al., 2016; Yamashita et al., 2016). fraction in most sites except for instance Ammonia tepida. This species dominate in eutrophic areas but where organic matter is in an oxide stage and regardless of whether there is or not gas seep. Foraminiferal density and diversity increased in areas with a prevalence of organic matter from oceanic biological production and declined in areas where organic matter and metals are retained in disoxic/anoxic phases of the sediments.

Keywords: Metals. Organic matter. Gas seep. Dimension of living foraminifera. Assemblages structure. Guanabara Bay

Several studies aiming to assess the environmental conditions in GB based on benthic foraminifera have been performed (Eichler et al., 2003; Vilela et al., 2004, 2007, 2011; Fontana et al., 2006; Kfouri-Cardoso et al., 2006; Donnici et al., 2012; Clemente et al., 2015). Due to the low abundance of living benthic foraminifera in GB, these works were based on the dead plus living (total) assemblages. However, according to Schönfeld et al. (2012), the environmental status evaluation must be exclusively based on the living assemblages of foraminifera.

Excluding the work of Delavy et al. (2016), this work is one of the first studies considering living foraminiferal assemblages in the bay and represents the first that considers the abundance and structure of the living benthic foraminiferal assemblages in selected sediment fractions.

\subsection{The main goals of this work}

The main aim of this research is to analyze the influence of organic matter and metals enrichment in the structure of living benthic foraminiferal assemblages in the NE sector of GB.

\section{Material and methods}

The structure of living benthic foraminiferal assemblages was analyzed in nine stations on 27 January 2016 in the NE of GB (Fig. 1; Table 1). At least three replicates of sediment were collected in each station by independent deployments of a box-corer. The first centimeter of sediments was removed and preserved for sedimentological and microfaunal analyses. Samples for microfaunal analyses were 
preserved with alcohol and Rose Bengal ( $2 \mathrm{~g}$ of Rose Bengal in $1000 \mathrm{ml}$ alcohol) to differentiate living from dead specimens (Schönfeld et al., 2012).

The methodology applied in the analyses of physicochemical parameters, grain size, $\delta^{13} \mathrm{C}$ in sedimentary organic matter, total organic carbon content (TOC), parameters of pyrolysis (Rock-Eval) and living foraminiferal data were described in Delavy et al. (2016). This work reanalyzed some of data obtained by Delavy et al. (2016), namely: percentage of fine fraction, TOC, $\delta^{13} \mathrm{C}$ and the S2 index values, as well as the total living assemblage of foraminifera found in each station. The S2 is the amount of hydrocarbon released from cracking organic compounds (mg HC/g sediment) and heavy hydrocarbons. This parameter is obtained by pyrolysis $\left(300-600^{\circ} \mathrm{C}\right)$ and is related to hydrocarbon source potential (Espitalié et al., 1977).

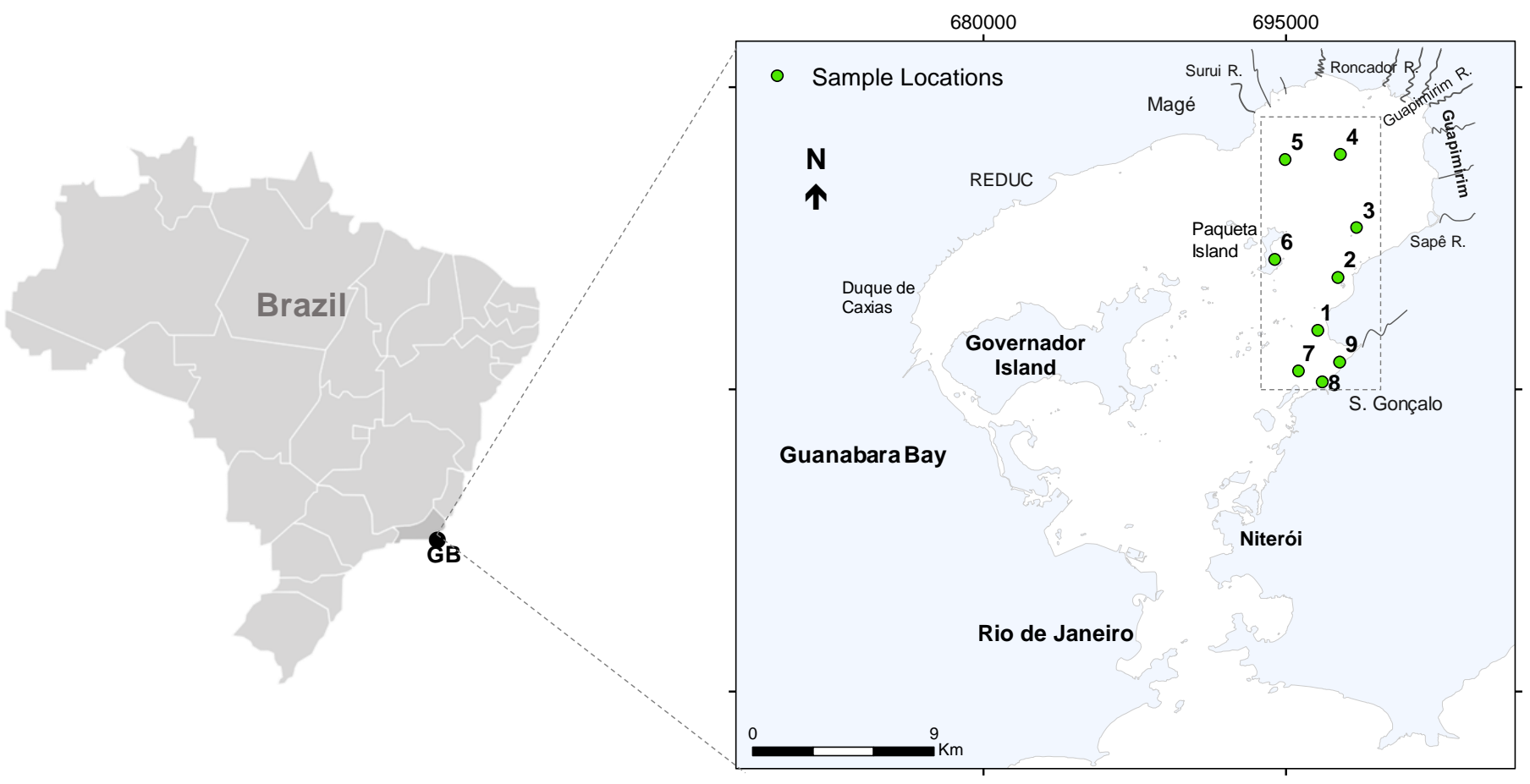

Fig.1. Samples locations in the NE sector of Guanabara Bay, Rio de Janeiro State (Brazil). Legend: S. Gonçalo - São Gonçalo; R. River, Reduc - oil refinery.

\subsection{Geochemical analyses and structure of living foraminifera}

New data analyzed in this work include: 1) total sulfur (TS) estimated in the Chemostratigraphy and Organic Geochemistry Laboratory of Universidade do Estado do Rio de Janeiro (LGQM-UERJ), with a LECO SC-632 equipment; 2) concentrations of $\mathrm{Cr}, \mathrm{Cu}, \mathrm{Pb}, \mathrm{Zn}, \mathrm{Sr}, \mathrm{Al}_{2} \mathrm{O}_{3}$, $\mathrm{Fe}_{2} \mathrm{O}_{3}, \mathrm{P}_{2} \mathrm{O}_{5}, \mathrm{CaO}, \mathrm{MnO}, \mathrm{MgO}$ and $\mathrm{SO}_{3}$ analyzed by X-Ray Fluorescence (XRF) technique with a Panalytical equipment (Axios model) in the Laboratory of X-Ray Diffraction
Analysis of Universidade de Aveiro (Portugal) in the fine fraction; 3) living benthic foraminiferal assemblages in four selected sediment fractions; $63-150 \mu \mathrm{m}, 150-250 \mu \mathrm{m}, 250$ $500 \mu \mathrm{m}$ and $>500 \mu \mathrm{m}$ were analyzed in the Laboratory of Micropaleontology of Universidade do Estado do Rio de Janeiro (LMP-UERJ).

In order to obtain a reliable characterization of the assemblage integrated in each granulometric fraction ideally, 300 living foraminiferal specimens were counted and identified in each size fraction $(63-150 \mu \mathrm{m}, 150-250 \mu \mathrm{m}, 250-$ 
$500 \mu \mathrm{m}$ and $>500 \mu \mathrm{m})$ of each sample composed by the sediment of three combined replicates.

Tab. 1. Geographic coordinates of studied stations in the NE area of Guanabara Bay. Samples were collected at about 2.5-5.5 m water depths.

\begin{tabular}{|l|c|c|}
\hline Station & Latitude & Longitude \\
\hline GB1 & $22^{\circ} 47^{\prime} 42.33^{\prime \prime} \mathrm{S}$ & $43^{\circ} 05^{\prime} 6.29^{\prime \prime} \mathrm{W}$ \\
\hline GB2 & $22^{\circ} 46^{\prime} 16.62^{\prime \prime} \mathrm{S}$ & $43^{\circ} 04^{\prime} 32.85^{\prime \prime} \mathrm{W}$ \\
\hline GB3 & $22^{\circ} 44^{\prime} 56.03^{\prime \prime} \mathrm{S}$ & $43^{\circ} 04^{\prime} 0.82^{\prime \prime} \mathrm{W}$ \\
\hline GB4 & $22^{\circ} 42^{\prime} 57.70^{\prime \prime} \mathrm{S}$ & $43^{\circ} 04^{\prime} 31.16^{\prime \prime} \mathrm{W}$ \\
\hline GB5 & $22^{\circ} 43^{\prime} 07.02^{\prime \prime} \mathrm{S}$ & $43^{\circ} 06^{\prime} 6.54^{\prime \prime} \mathrm{W}$ \\
\hline GB6 & $22^{\circ} 45^{\prime} 48.52^{\prime \prime} \mathrm{S}$ & $43^{\circ} 06^{\prime} 22.53^{\prime \prime} \mathrm{W}$ \\
\hline GB7 & $22^{\circ} 48^{\prime} 48.27^{\prime \prime} \mathrm{S}$ & $43^{\circ} 05^{\prime} 38.48^{\prime \prime} \mathrm{W}$ \\
\hline GB8 & $22^{\circ} 49^{\prime} 05.2^{\prime \prime} \mathrm{S}$ & $43^{\circ} 04^{\prime} 57.5^{\prime \prime} \mathrm{W}$ \\
\hline GB9 & $22^{\circ} 48^{\prime} 33.00^{\prime \prime} \mathrm{S}$ & $43^{\circ} 04^{\prime} 27.80^{\prime \prime} \mathrm{W}$ \\
\hline
\end{tabular}

The species identification followed the same methodology described in Delavy et al. (2016). Sediment fractions with a number of living organisms $<100$ were not considered in statistical analysis. Ecological indexes such as specific richness (S), Shannon Index $\left(\mathrm{H}^{\prime}\right)$ and equitability (J') were determined in each sediment fraction (with $>100$ specimens). Foraminiferal density (FD) was calculated as the number of living specimens in each sediment fraction per gram of bulk sediment. Despite foraminiferal species have different dimensions, considering that there were no foraminifera found in the $>500 \mu \mathrm{m}$ sediment fraction, we assume that specimens occurring in the sediment fraction 63-500 $\mu \mathrm{m}$ represent the living foraminiferal assemblage (LFA) in each station. In order to simplify the data discussion we refer the living specimens identified in the 63$150 \mu \mathrm{m}$ sedimentary fraction as foraminifera of the fine fraction (FFF); 150-250 $\mu \mathrm{m}$ sediment fraction as foraminifera of the medium fraction (FMF) and 250-500 $\mu \mathrm{m}$ sedimentary fraction as foraminifera of coarse faction (FCF).

\subsection{Statistical analysis}

Biotic and abiotic data were logarithmically transformed $\log (\mathrm{X}+1)$ before the statistical analysis. The most frequent foraminiferal species (with a relative abundance $\geq 3 \%$ and an occurrence in at least three stations), assemblages parameters
(FD, H' and J') by station and the relative abundance of living species found in each sediment fraction (with enough foraminifera as refereed above) were compared with selected abiotic data by Principal Components Analysis (PCA). Spearman correlations between the analyzed variables were also determined. Correlations are significant at $p<0.05$.

Statistical analyses were performed with the software Statistica v.12. Maps were performed with Arc Gis $9.2 \AA$ using coordinates according to WGS84 (UTM 23) datum.

\section{Results}

Water temperature was relatively high (mean $30.2^{\circ} \mathrm{C}$ ) and salinity varied between 12.1 and 35.9 (mean 24.4) during the sampling event. The lowest values of salinity were recorded near the rivers mouths.

The water column presented mean dissolved oxygen values of $7.0 \mathrm{mg} / \mathrm{l}$ and basic $\mathrm{pH}$ values from 7.7 to 8.5 (mean 8.3). The lowest $\mathrm{pH}$ values were recorded in station GB5 under the Suruí River outflow.

\subsection{Sediments characteristics and metals concentrations}

The sediments are mainly composed of mud to muddy sand particles with mean grain size varying from 17-125 $\mu \mathrm{m}$ (mean $42 \mu \mathrm{m}$ ). In these sediments, the fine fractions ranged from $27 \%$ to $94.6 \%$ (mean $72.9 \%$; Table 2).

In all the stations, the sediments were poorly sorted and composed by trimodal to polymodal particles except in station GB3, which had unimodal sedimentary particles. The mean values of sediments characteristics and metals concentrations are reported in Table 2.

The highest concentrations of metals such as $\mathrm{Cr}$ (Fig. 2A), $\mathrm{Cu}$ (Fig. 2B), Pb (Fig. 2C) and Zn (Fig. 2D) were mostly found near São Gonçalo city. A slight increase of $\mathrm{Cu}$ (Fig. 2B) and $\mathrm{Pb}$ (Fig. 2C) was also observed in Paquetá Island and of $\mathrm{Pb}$ in front of the Sapé River (Fig. 2C).

The lowest $\mathrm{CaO}$ content was observed in the inner area of the $\mathrm{NE}$ region of $\mathrm{GB}$ (Fig. 3A). The highest concentrations of $\mathrm{P}_{2} \mathrm{O}_{5}$ (Fig. 3B) were observed near the Suruí River and São Gonçalo city.

The contents of $\mathrm{Al}_{2} \mathrm{O}_{3}$ (Fig. 3C) and $\mathrm{Fe}_{2} \mathrm{O}_{3}$ increased mostly in front of rivers mouths (Fig. 3D). The distribution pattern of $\mathrm{MnO}$ (Fig. 3E) and $\mathrm{SO}_{3}$ (Fig. 3F) contents presented opposite trends. The highest $\mathrm{MnO}$ values were recorded in the outer stations. 


\subsection{Living foraminiferal assemblages}

According to data presented in Delavy et al. (2016), a total of 46 taxa were recognized in the studied area. The specific richness varied between 6 and 30 excluding station GB8 that was basically devoid of living foraminifera. The highest species values were found in the most external stations (GB7, GB6 and GB1). The highest values of H' (0.25-1.75)

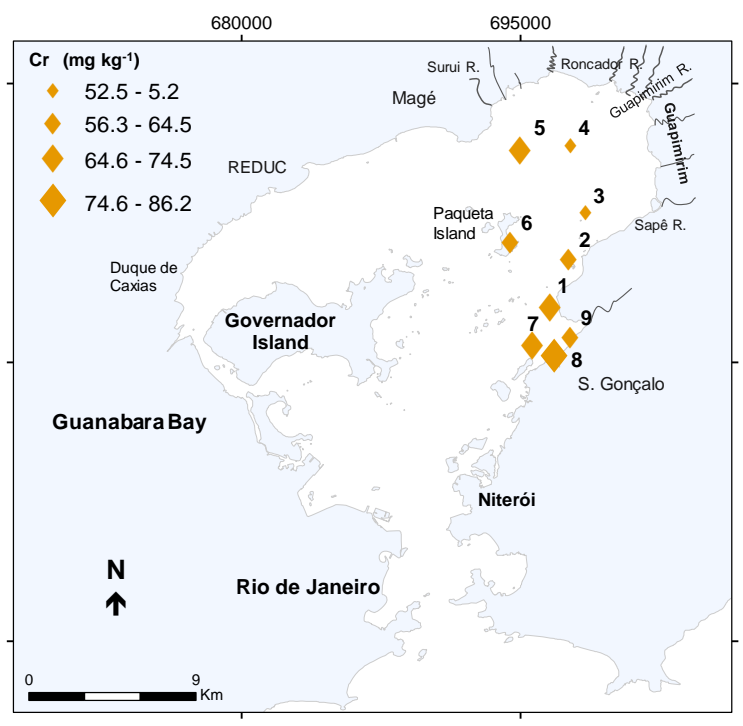

A

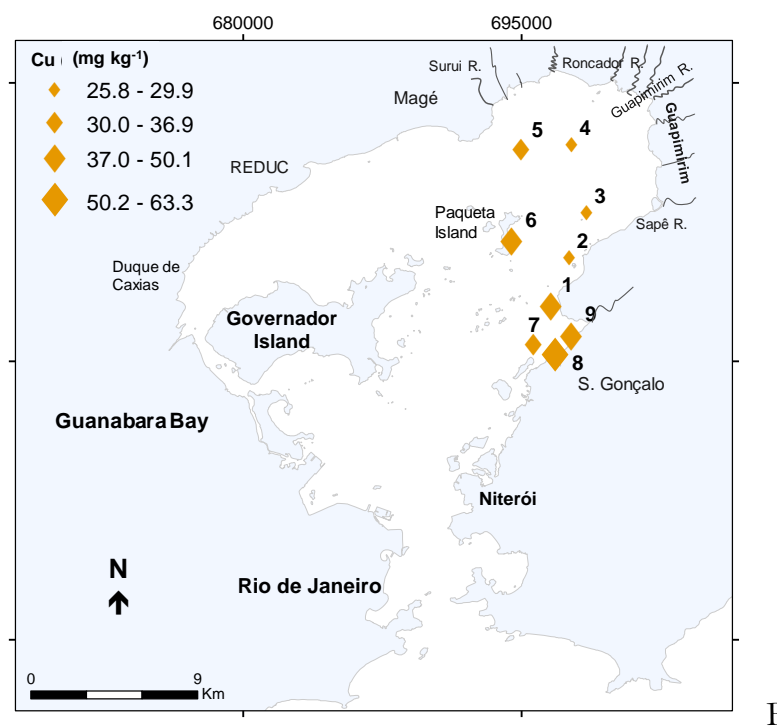

B

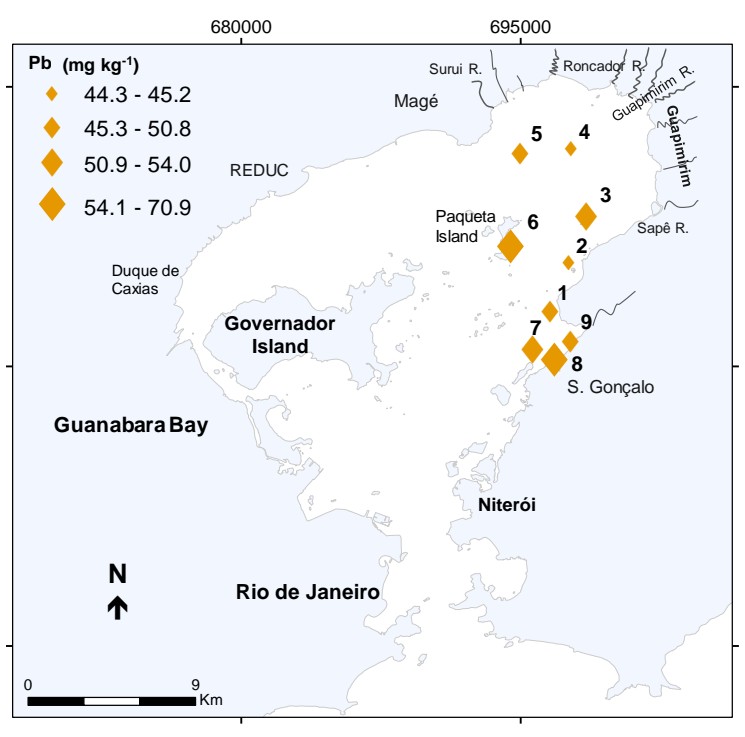

C

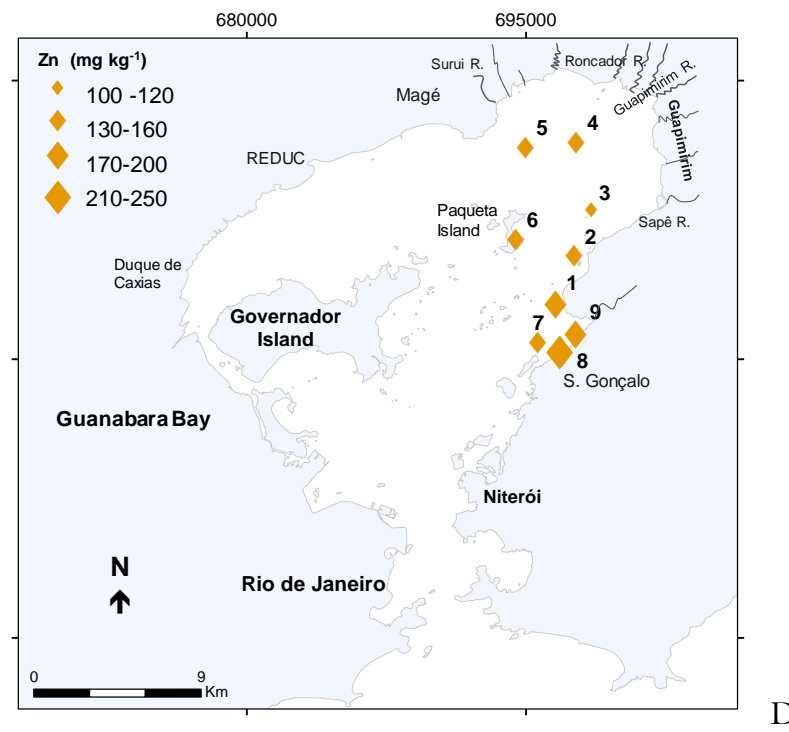

Fig. 2. Maps of distribution of concentrations: A. Cr $\left(\mathrm{mg} \mathrm{kg}^{-1}\right)$; B. $\mathrm{Cu}\left(\mathrm{mg} \mathrm{kg}^{-1}\right)$; C. Pb (mg kg$\left.{ }^{-1}\right)$ and; $\mathrm{D} . \mathrm{Zn}\left(\mathrm{mg} \mathrm{kg}^{-1}\right)$. Legend: S. Gonçalo - São Gonçalo; R. - River; Reduc - oil refinery. 
Tab. 2 - Sedimentary data of the studied stations in the NE sector of Guanabara Bay. Maximum (max), minimum (Min) and mean values for each variable are indicated.

\begin{tabular}{|c|c|c|c|c|c|c|c|c|c|c|c|c|c|}
\hline \multicolumn{2}{|c|}{ Variables/Stations } & \multirow{2}{*}{$\begin{array}{c}\text { GB1 } \\
92.3 \\
\end{array}$} & \multirow{2}{*}{$\begin{array}{c}\text { GB2 } \\
94.6\end{array}$} & \multirow{2}{*}{$\begin{array}{c}\text { GB3 } \\
93.6 \\
\end{array}$} & \multirow{2}{*}{$\begin{array}{c}\text { GB4 } \\
92.2 \\
\end{array}$} & \multirow{2}{*}{$\begin{array}{c}\text { GB5 } \\
79.4 \\
\end{array}$} & \multirow{2}{*}{$\begin{array}{c}\text { GB6 } \\
62.8 \\
\end{array}$} & \multirow{2}{*}{$\begin{array}{c}\text { GB7 } \\
27.0 \\
\end{array}$} & \multirow{2}{*}{$\begin{array}{c}\text { GB8 } \\
29.3 \\
\end{array}$} & \multirow{2}{*}{\begin{tabular}{|c|} 
GB9 \\
84.8 \\
\end{tabular}} & \multirow{2}{*}{$\begin{array}{c}\text { Max } \\
94.6\end{array}$} & \multirow{2}{*}{$\begin{array}{c}\text { Min } \\
27.0 \\
\end{array}$} & \multirow{2}{*}{$\begin{array}{r}\text { Mean } \\
72.9\end{array}$} \\
\hline Fines & $\%$ & & & & & & & & & & & & \\
\hline TOC & $\%$ & 4.21 & 4.44 & 4.68 & 4.22 & 5.80 & 1.98 & 2.54 & 1.50 & 4.23 & 5.8 & 1.5 & 3.7 \\
\hline TS & $\%$ & 1.60 & 1.80 & 1.60 & 1.80 & 2.10 & 1.00 & 1.10 & 0.75 & 1.40 & 2.10 & 0.75 & 1.46 \\
\hline $\mathrm{C} / \mathrm{S}$ & & 2.63 & 2.47 & 2.93 & 2.34 & 2.76 & 1.98 & 2.31 & 2.00 & 3.02 & 3.02 & 1.98 & 2.49 \\
\hline$\delta^{13} \mathrm{C}$ & $\%$ & -22.24 & -23.11 & -24.56 & -24.27 & -21.60 & -21.69 & -21.73 & -23.95 & -24.34 & -21.60 & -24.56 & -23.05 \\
\hline S2 & mg HC/g sediment & 7.7 & 7.4 & 6.4 & 5.4 & 10.5 & 3.4 & 4.2 & 2.7 & 8.4 & 10.5 & 2.7 & 6.2 \\
\hline $\mathrm{Cr}$ & $\mathrm{mg} \mathrm{kg}^{-1}$ & 69.1 & 60.9 & 56.2 & 52.5 & 68.5 & 63.6 & 74.5 & 86.2 & 64.5 & 86.2 & 52.5 & 66.2 \\
\hline $\mathrm{Cu}$ & $\mathrm{mg} \mathrm{kg}^{-1}$ & 43.5 & 26.2 & 29.9 & 25.8 & 36.9 & 50.1 & 35.2 & 63.3 & 47.3 & 63.3 & 25.8 & 39.8 \\
\hline $\mathbf{P b}$ & $\mathrm{mg} \mathrm{kg}^{-1}$ & 49.9 & 44.3 & 52.1 & 45.2 & 50.8 & 64.5 & 54.0 & 70.9 & 47.6 & 70.9 & 44.3 & 53.3 \\
\hline $\mathrm{Zn}$ & $\mathrm{mg} \mathrm{kg}^{-1}$ & 170 & 140 & 100 & 130 & 160 & 150 & 160 & 250 & 190 & 250 & 100 & 161 \\
\hline $\mathrm{Sr}$ & $\mathrm{mg} \mathrm{kg}^{-1}$ & 90 & 80 & 90 & 100 & 90 & 120 & 200 & 110 & 120 & 200 & 80 & 111 \\
\hline MgO & $\%$ & 1.82 & 1.78 & 1.75 & 1.97 & 1.87 & 1.52 & 1.25 & 0.85 & 2.10 & 2.1 & 0.9 & 1.7 \\
\hline $\mathrm{MnO}$ & $\mathrm{mg} \mathrm{kg}^{-1}$ & 920 & 890 & 570 & 530 & 720 & 760 & 880 & 460 & 490 & 920 & 460 & 691 \\
\hline $\mathrm{Al}_{2} \mathrm{O}_{3}$ & $\%$ & 14.8 & 13.9 & 16.5 & 20.6 & 16.4 & 11.0 & 12.8 & 9.1 & 20.3 & 20.6 & 9.1 & 15.0 \\
\hline $\mathrm{CaO}$ & $\%$ & 0.72 & 0.50 & 0.44 & 0.44 & 0.43 & 2.21 & 0.89 & 0.40 & 0.94 & 2.21 & 0.40 & 0.78 \\
\hline $\mathrm{Fe}_{2} \mathrm{O}_{3}$ & $\%$ & 6.23 & 6.07 & 6.94 & 8.16 & 6.48 & 5.55 & 6.43 & 6.29 & 6.83 & 8.16 & 5.55 & 6.55 \\
\hline $\mathbf{P}_{2} \mathbf{O}_{5}$ & $\%$ & 0.16 & 0.14 & 0.17 & 0.24 & 0.26 & 0.13 & 0.14 & 0.11 & 0.27 & 0.27 & 0.11 & 0.18 \\
\hline $\mathrm{SO}_{3}$ & $\%$ & 2.97 & 3.10 & 3.31 & 3.27 & 3.92 & 2.23 & 2.23 & 2.27 & 3.55 & 3.92 & 2.23 & 2.98 \\
\hline
\end{tabular}



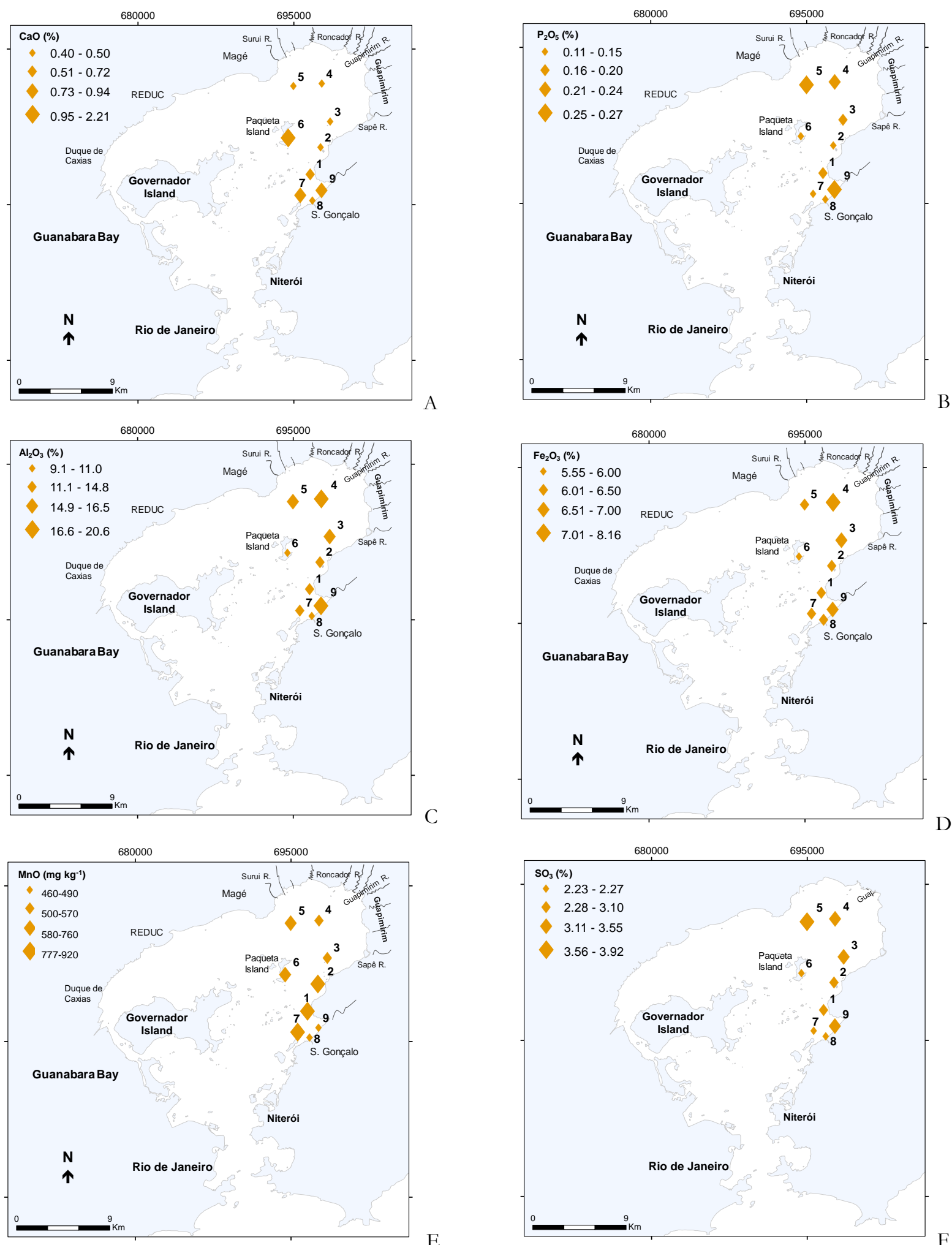

C

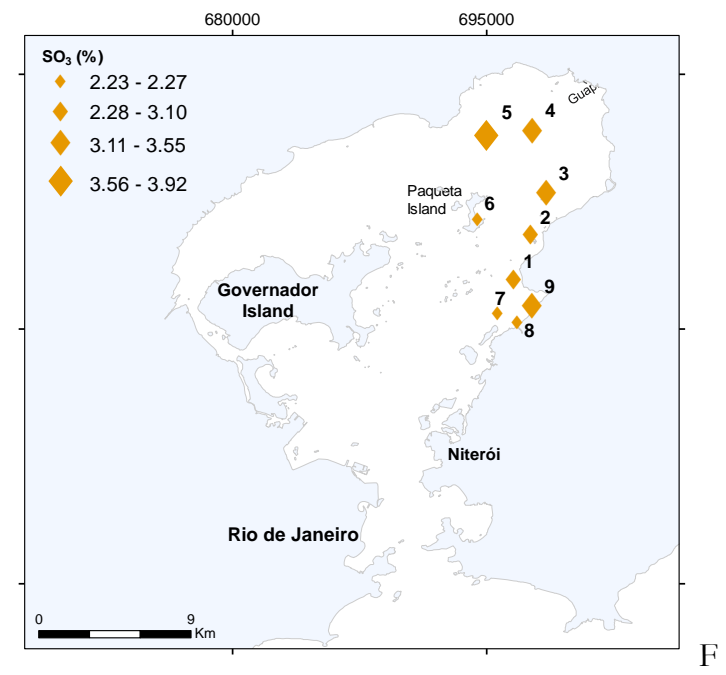

Fig. 3. Maps of distribution of concentrations: A. $\mathrm{CaO}(\%)$; B. $\mathrm{P}_{2} \mathrm{O}_{5}(\%)$; C. $\mathrm{Al}_{2} \mathrm{O}_{3}(\%)$; D. $\mathrm{Fe}_{2} \mathrm{O}_{3}(\%)$. E. $\mathrm{MnO}(\%) ; \mathrm{F} . \mathrm{SO}_{3}(\%)$. Legend: S. Gonçalo - São Gonçalo; R. - River; Reduc - oil refinery. 


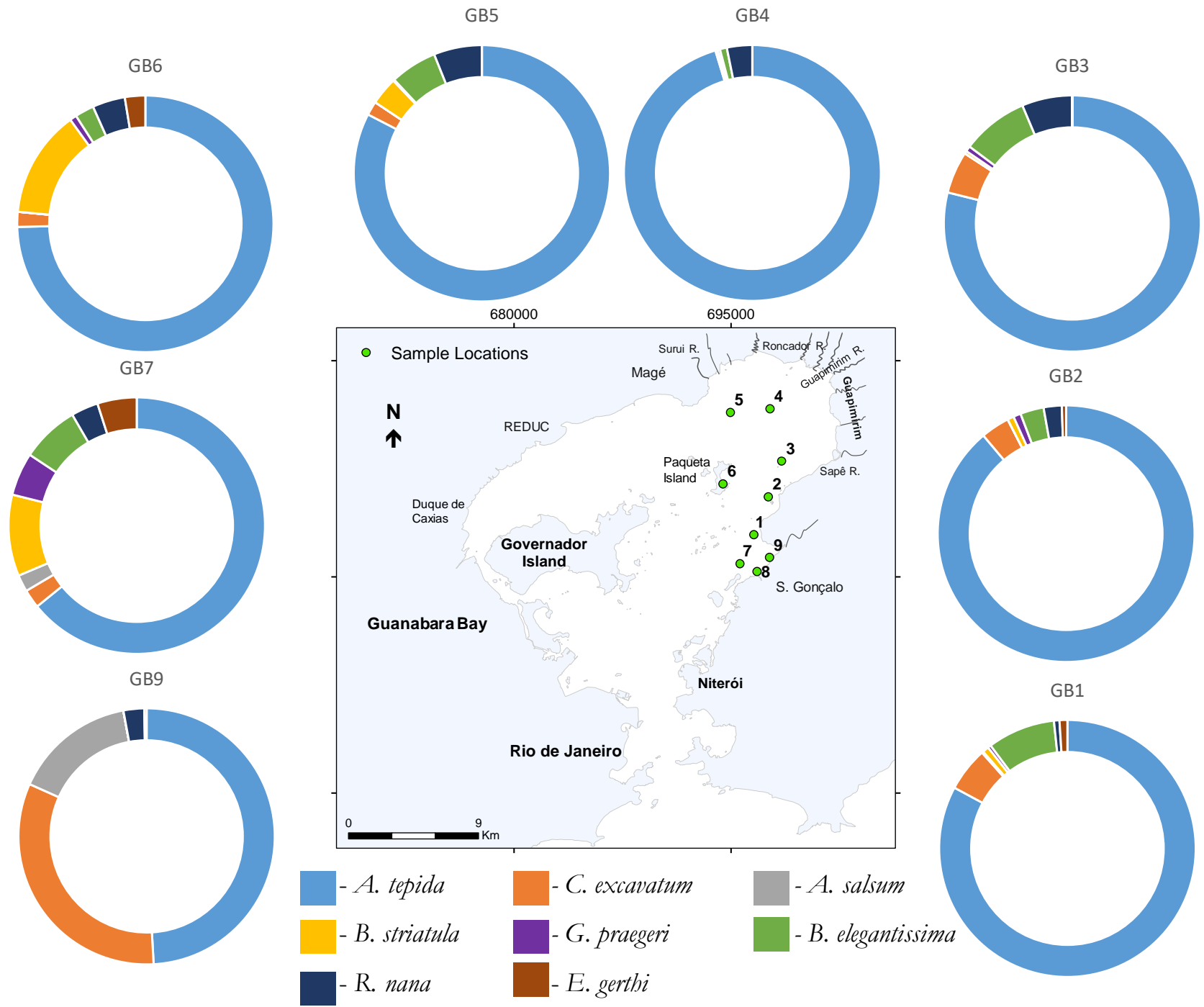

Fig. 4. Relative abundance of the main living benthic foraminiferal species from the NE sector of Guanabara Bay. Legend: S. Gonçalo - São Gonçalo; R. - River; Reduc - oil refinery.

\subsection{Living foraminifera in sediment fractions}

The percentages of living benthic foraminifera on three sediment fractions $(63-150 \mu \mathrm{m}, 150-250 \mu \mathrm{m}$ and $250-500$ $\mu \mathrm{m})$ and all the foraminiferal assemblages parameters $(\mathrm{N}$, FD, S, H' and J') are presented in Appendix 1.

The sediment fraction $>500 \mu \mathrm{m}$ was discarded due to the absence of living foraminifera. No living specimens were found in the 250-500 $\mu \mathrm{m}$ sediment fraction for most of the stations (Fig. 5A; Appendix 1) and only rare living specimens were recorded in stations GB1, GB2 and GB5. The highest abundances of living organisms were found in the $63-150 \mu \mathrm{m}$ and 150-250 $\mu \mathrm{m}$ sediment fractions. The abundance of living foraminifera was similar in both sediment fractions in stations GB1 and GB2 (Fig. 5A). The highest FD was found in the 63-150 $\mu \mathrm{m}$ sediment fraction followed by the 150-250 $\mu \mathrm{m}$ one in the GB4, GB5 and GB6 stations, an inverse pattern was documented in stations GB7 and GB9. The living assemblage comprehended only living organisms with dimensions varying between 150-250 $\mu \mathrm{m}$ in GB9 (Fig. 5A). 
Foraminiferal Density (n. $\% / g)$

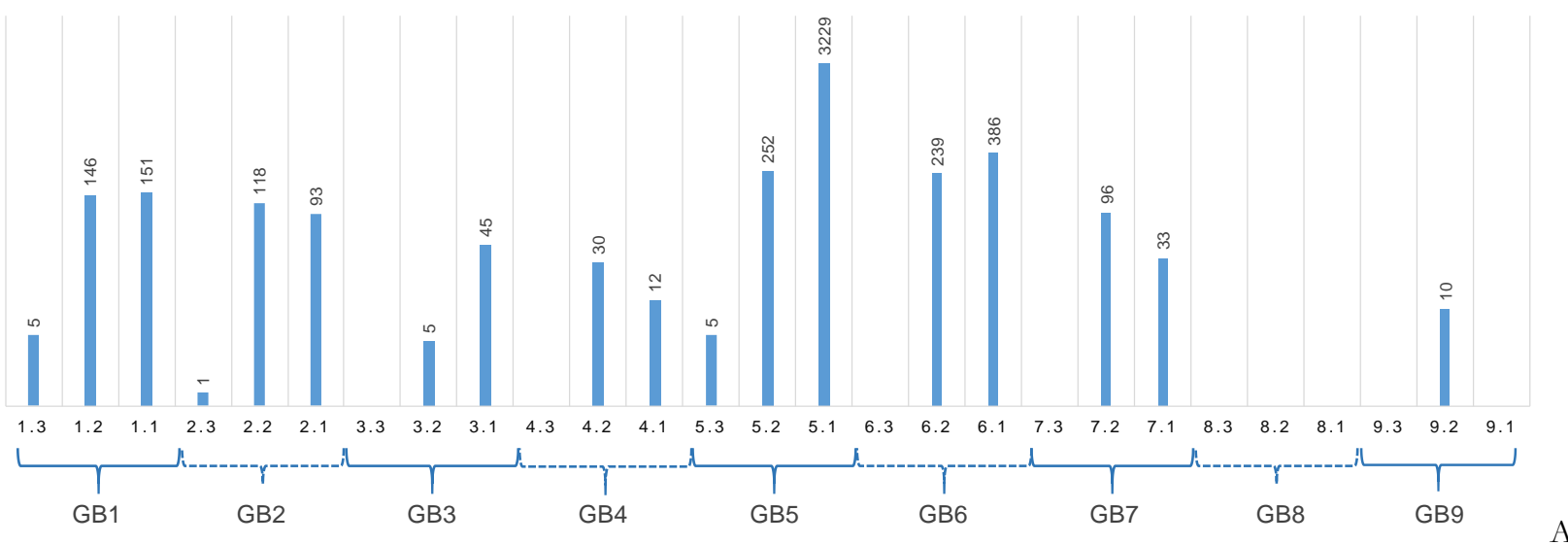

Shannon Index

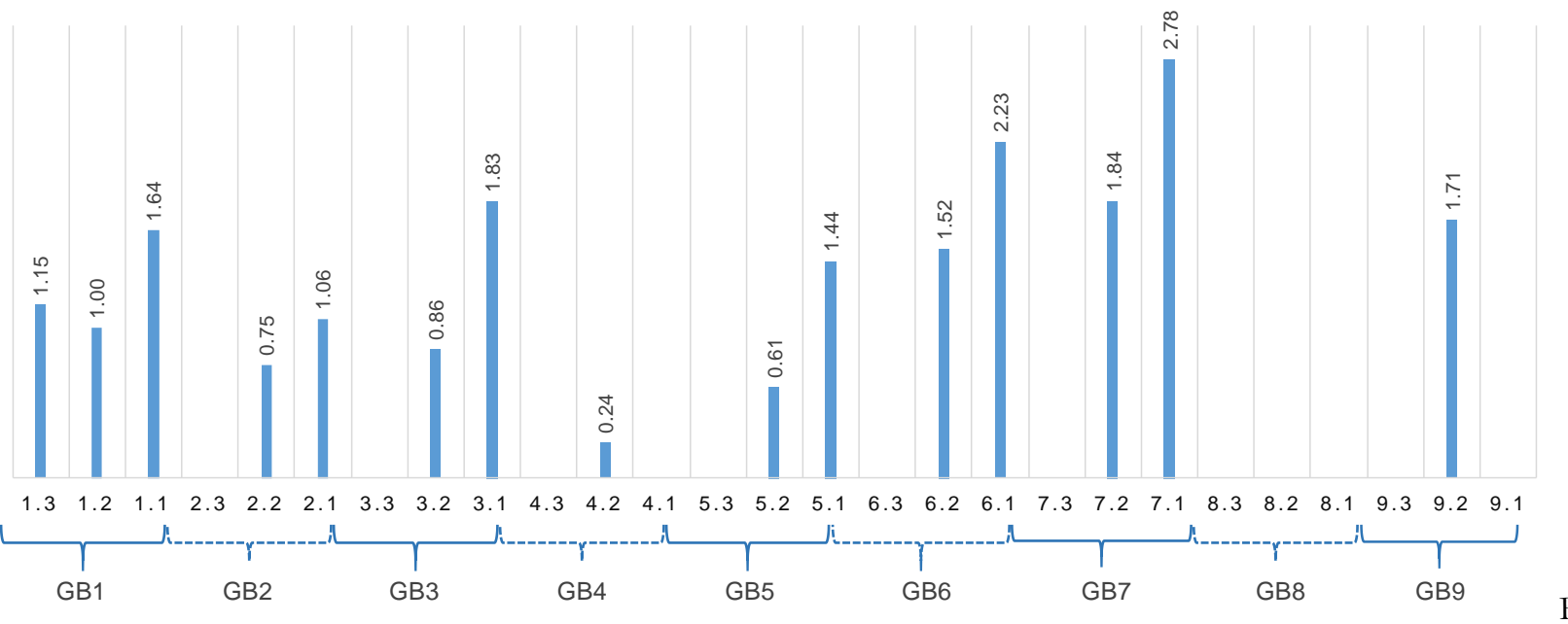

Equitability

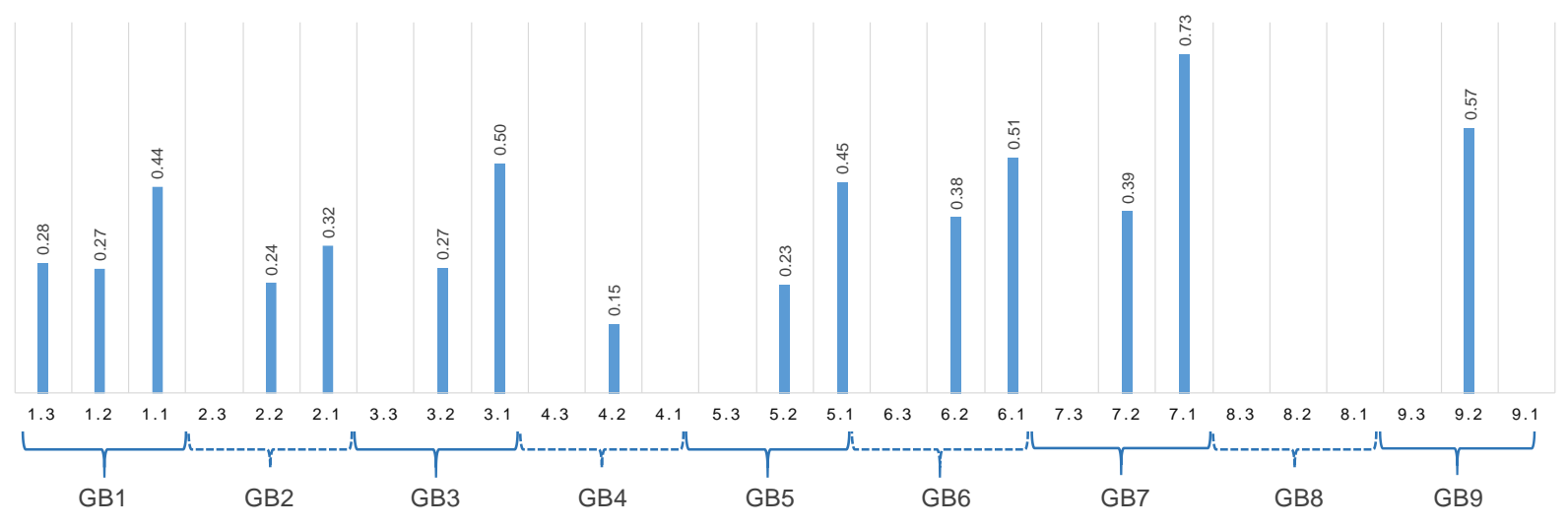

C

Fig. 5. Bar graphs of the following variables in each sediment fraction of the studied samples (1-9) in the NE sector of Guanabara Bay. A. Foraminiferal density (logarithmic vertical scale); B. Shannon Index and; C. Equitability. Stations (1-9) and sediment fractions: 3. 250$500 \mu \mathrm{m}(1.3-9.3) ; 2.150-250 \mu \mathrm{m}(1.2-9.2) ; 1.63-150 \mu \mathrm{m}(1.1-9.1)$. 


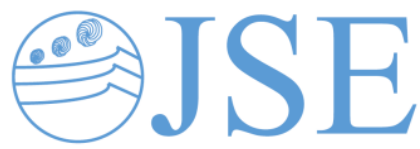

RESEARCH PAPER
The specific richness $(\mathrm{S}<26$ species), Shannon index $\left(\mathrm{H}^{\prime}<2.78\right.$; Fig. $\left.5 \mathrm{~B}\right)$ and equitability $\left(\mathrm{J}^{\prime}<0.73\right.$; Fig. $\left.5 \mathrm{C}\right)$ values followed the trend of FD (Fig. 5; Appendix 1). The highest values of $\mathrm{S}$ were documented for GB6 and GB7 stations in the sediment fraction $63-150 \mu \mathrm{m}$, whereas the highest ones of H' and J' were recognized at stations GB7, GB6 and GB3, in the same sediment fraction.

Ammonia tepida, the most dominant species in the studied stations (Fig. 6A), co-dominated with $C$. excavatum in sediment fraction 150-250 $\mu \mathrm{m}$ of station GB9 (Fig. 6B). Buliminella elegantissima reached the highest relative abundance in the 63-150 $\mu \mathrm{m}$ sediment fraction of stations GB1, GB3 and GB5 (Fig. 6C).

Bolivina striatula was mostly represented in the $63-150 \mu \mathrm{m}$ sediment fraction of GB6 and GB5 (Appendix 1). This species also reached up to $8 \%$ of the assemblage in GB6, in the 150-250 $\mu \mathrm{m}$ sediment fraction. Ammotium salsum was poorly represented in the living assemblage but peaked $15 \%$ in 150-250 $\mu \mathrm{m}$ sediment fraction of station GB9 (Appendix 1). Bolivinids and buliminids group, which includes Bolivina compacta, Bolivina lowmani, Bolivina striatula, Bulimina aculeata, Bulimina gibba and Bulimina marginata (but not Buliminella elegantissima), reached relatively high percentages in stations GB5-GB7 and GB1, mostly in the 63-150 $\mu \mathrm{m}$ sediment fraction (Fig. 6D).

\subsection{Relationships among benthic foraminiferal species and abiotic variables}

The main living benthic foraminiferal species and assemblages parameters were compared with selected abiotic variables through Spearman correlations (Appendix 2) and principal components analysis (PCA). The two first factors, which explain $68 \%$ of data variability $(42 \%$ and $26 \%$ by Factor 1 and Factor 2, respectively), separate three main groups of variables (Fig. 7). Group I encloses $A$. tepida, $C$. excavatum, $\mathrm{R}$. nana, as well as fine fraction, TOC, $\mathrm{Al}_{2} \mathrm{O}_{3}, \mathrm{P}_{2} \mathrm{O}_{5}$, $\mathrm{SO}_{3}, \mathrm{Fe}_{2} \mathrm{O}_{3}, \mathrm{MgO}, \mathrm{C} / \mathrm{S}$ and S2; Group II includes $\mathrm{Cr}, \mathrm{Cu}, \mathrm{Pb}$ and $\mathrm{Zn}$; and Group III comprises $\mathrm{CaO}, \mathrm{MnO}, \mathrm{Sr}, \delta^{13} \mathrm{C}, \mathrm{FD}$, H', J', B. elegantissima, B. striatula, Elphidium gerthi and Gavelinopsis praegeri, as well as $A$. tepida and R. nana.

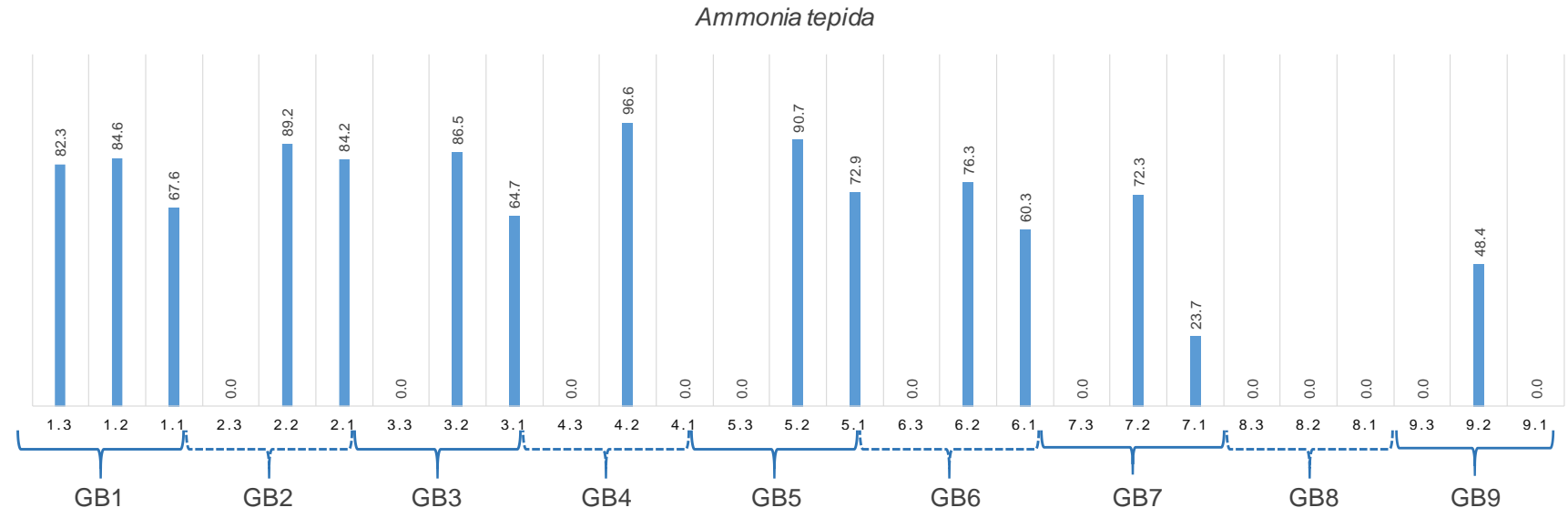

Fig. 6. Percentages of selected living species/group of species in the NE region of Guanabara Bay (GB1-GB9), in each station (1-9) and sediment fraction: 3. 250-500 $\mu \mathrm{m}$ (1.3-9.3); 2. 150-250 $\mu \mathrm{m}$ (1.2-9.2); 1. 63-150 $\mu \mathrm{m}$ (1.1-9.1).

\subsubsection{Living benthic foraminifera in sediment fractions}

The same abiotic variables were compared with the percentage of the most abundant foraminiferal species identified in different sediment fractions by PCA analysis (Fig. 8) and Spearman correlations (Appendix 3).The two first factors, which explain together $61 \%$ of data variability (Factor 1: 32\% and Factor 2: 29\%), identified three main groups of variables. Group I comprises $\mathrm{Al}_{2} \mathrm{O}_{3}, \mathrm{P}_{2} \mathrm{O}_{5}, \mathrm{SO}_{3}$,
$\mathrm{Fe}_{2} \mathrm{O}_{3}, \mathrm{MgO}, \mathrm{C} / \mathrm{S}, \mathrm{S} 2$, TOC, fines as well as $A$. tepida and $\mathrm{R}$. nana in the $63-150 \mu \mathrm{m}$ and $150-250 \mu \mathrm{m}$ sediment fractions and B. lowmani and C. excavatum in the $63-150 \mu \mathrm{m}$ sediment fraction. Group II encloses $\mathrm{Cr}, \mathrm{Cu}, \mathrm{Pb}$ and $\mathrm{Zn}$. Group III includes $\mathrm{CaO}, \mathrm{Sr}, \mathrm{MnO}, \delta^{13} \mathrm{C}, \mathrm{FD}, \mathrm{H}^{\prime}$ and J', as well as $A$. tepida, B. elegantissima, B. striatula, E. gerthi G. praegeri and T. inflata in the 63-150 $\mu \mathrm{m}$ and $150-250 \mu \mathrm{m}$ sediment fractions and R. nana only in 150-250 $\mu \mathrm{m}$ sediment fraction. 
Cribroelphidium excavatum

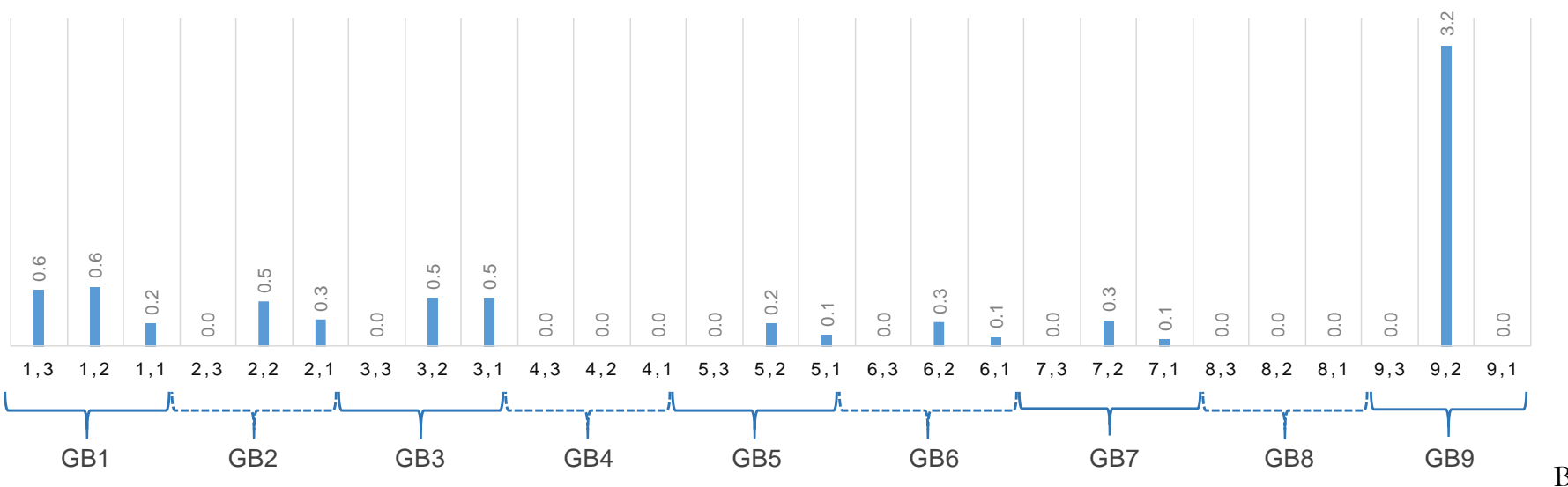

Buliminella elegantissima

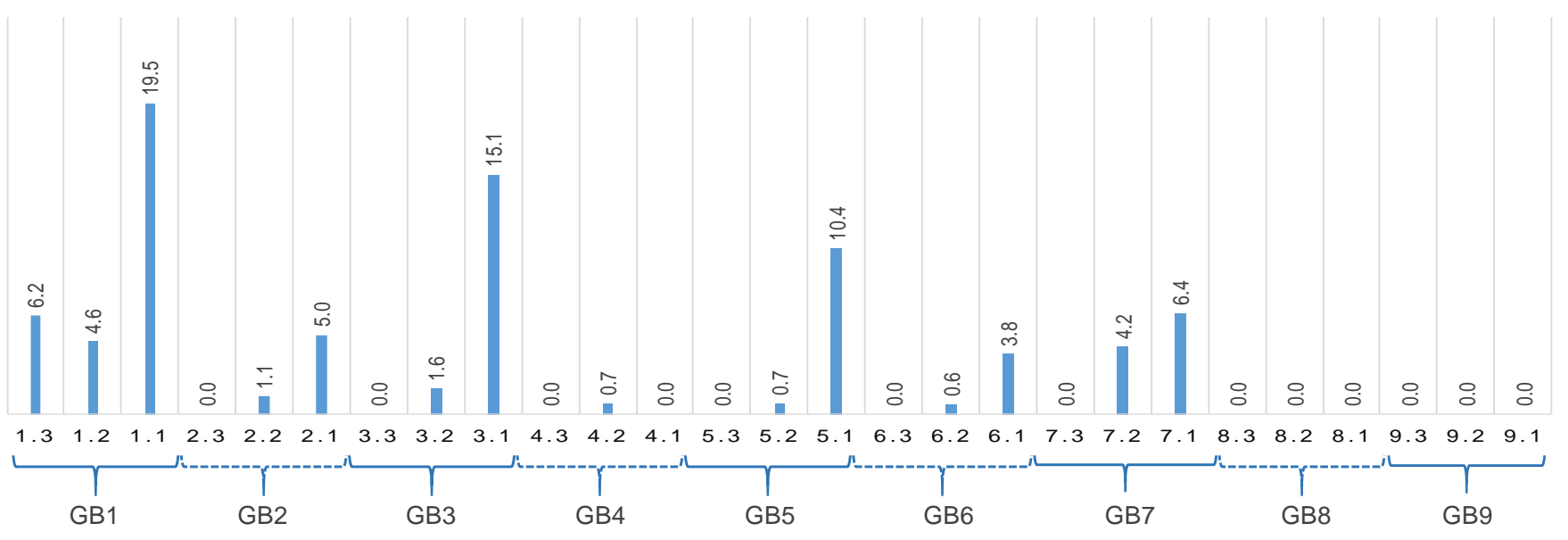

C

Bolivinids and Buliminids

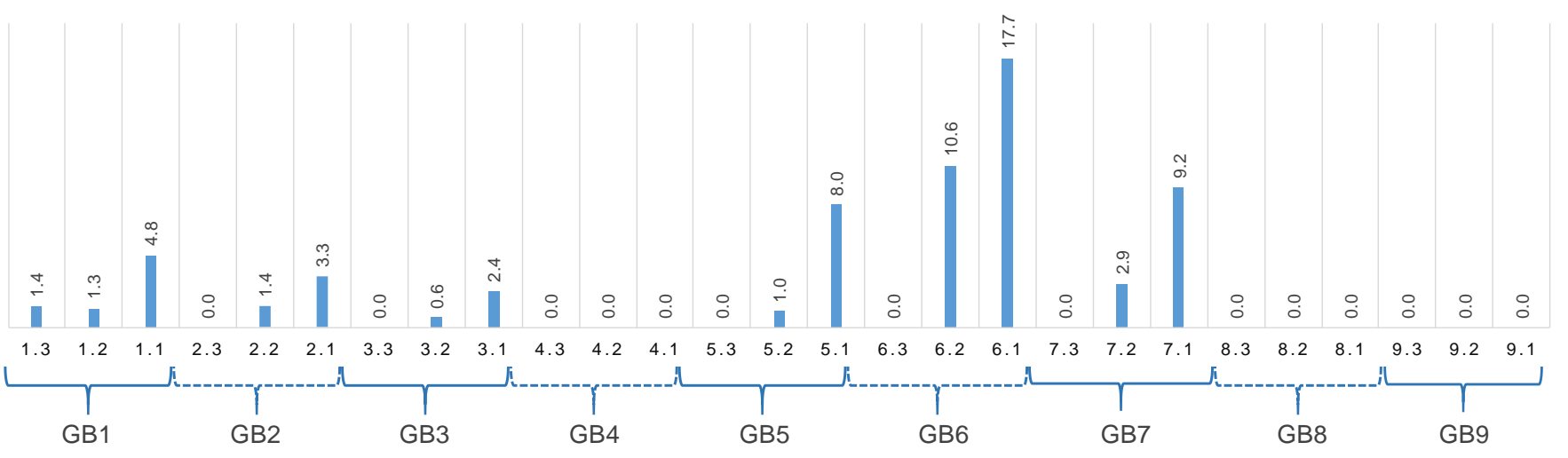

$\mathrm{D}$

Fig. 6 (cont.). Percentages of selected living species/group of species in the NE region of Guanabara Bay (GB1-GB9), in each station (1-9) and sediment fraction: 3. 250-500 $\mu \mathrm{m}$ (1.3-9.3); 2. 150-250 $\mu \mathrm{m}$ (1.2-9.2); 1. 63-150 $\mu \mathrm{m}$ (1.1-9.1). 


\section{Discussion}

\subsection{Sedimentological characteristics}

The particle size characteristics of the studied area indicate that the bottom hydrodynamic regime is generally characterized by relatively calm currents in most of the stations. The $\mathrm{CaO}$ values are low that suggest that the sediments are essentially terrigenous. In fact, the low water depth $<5 \mathrm{~m}$, the vicinity of the analyzed stations to the coast, the presence of low bottom hydrodynamism in this inner region of the bay and the dense hydrographic network contribute to the deposition of fine grained terrigenous sediments enriched in organic matter.

According to the correlation matrix (Appendix 2), fine fraction is positively correlated with $\mathrm{Al}_{2} \mathrm{O}_{3}, \mathrm{Fe}_{2} \mathrm{O}_{3}, \mathrm{SO}_{3}$, $\mathrm{P}_{2} \mathrm{O}_{5}, \mathrm{MgO}, \mathrm{S} 2, \mathrm{C} / \mathrm{S}$ and TOC. The positive correlation between $\mathrm{Al}_{2} \mathrm{O}_{3}$ and $\mathrm{Fe}_{2} \mathrm{O}_{3}$ concentrations and fine fraction content might be associated with the mineralogical composition of the sediments, probably to an increased amount of phyllosilicates. Concentrations of $\mathrm{Al}_{2} \mathrm{O}_{3}$ and $\mathrm{Fe}_{2} \mathrm{O}_{3}$ (Fig. 3) increased mostly in front of the rivers mouths and might be related to the terrigenous inputs of the rivers.
The highest concentrations of $\mathrm{P}_{2} \mathrm{O}_{5}$ (Fig. 2B) were observed near the Suruí River and São Gonçalo city probably in relation to the release of municipal and agricultural waste water. The increased supply of phosphates in these zones may amplify the biological productivity and contribute to the enhanced organic matter quantity deposited in the sediments. The $\mathrm{C} / \mathrm{S}$ ratio values are $<3$ in most of the samples of the NE sector of Guanabara Bay (Table 2) which indicate reducing conditions (Stein, 1991; Borrego et al., 1998).

In light of it, it can be inferred that higher TOC content might promote an increase in biogeochemical reactions in the sediment water interface that may influence the concentrations of several chemical elements in different sedimentological phases. The consumption of oxygen by aerobic organisms that degrade organic matter can lead to dysoxic/anoxic conditions in subsurface of the sediments in some stations (as signed by black color). However, the highest values of TOC are positively correlated to the $\mathrm{Al}_{2} \mathrm{O}_{3}$, $\mathrm{P}_{2} \mathrm{O}_{5}, \mathrm{SO}_{3}, \mathrm{Fe}_{2} \mathrm{O}_{3}, \mathrm{MgO}$ concentrations (Appendix 2), which should indicate that, in areas where these oxides increase, the surface organic matter is newly deposited and is yet in an oxidant sedimentary phase.

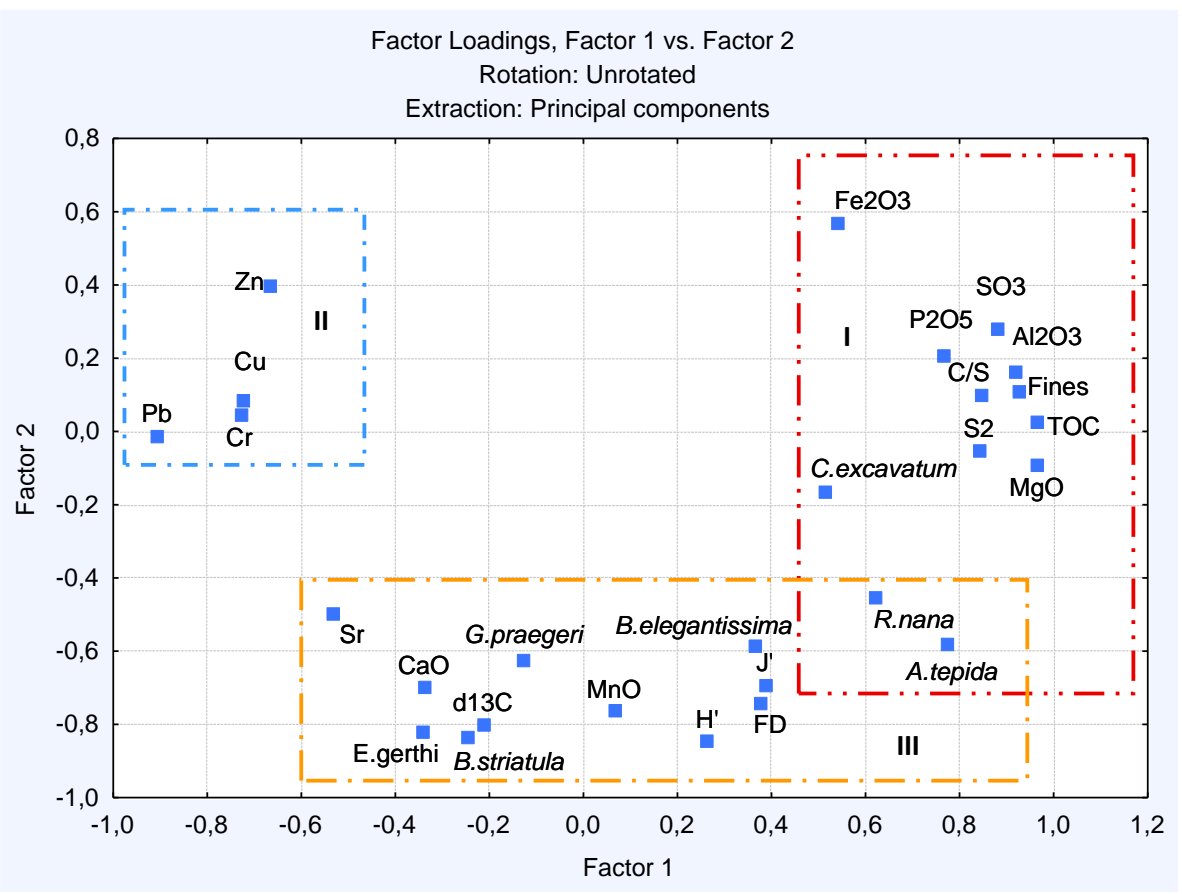

Fig. 7. Principal Component Analysis based on: concentrations of $\mathrm{Cr}, \mathrm{Cu}, \mathrm{Pb}, \mathrm{Zn}, \mathrm{Sr}, \mathrm{Al}_{2} \mathrm{O}_{3}\left(\mathrm{Al}_{3} \mathrm{O}_{3}\right), \mathrm{P}_{2} \mathrm{O}_{5}\left(\mathrm{P}_{2} \mathrm{O}_{5}\right), \mathrm{SO}_{3}(\mathrm{SO} 3), \mathrm{Fe}_{2} \mathrm{O}_{3}$ (Fe2O3), $\mathrm{CaO}$ and $\mathrm{MnO}$; percentage of fine fraction (Fines), TOC, A. tepida, C. excavatum, R. nana, B. elegantissima, B. striatula, E. gerthi and G. praegeri, Foraminiferal density (FD), Shannon index ( $\left.\mathrm{H}^{\prime}\right)$, equitability (J'), S2, $\delta^{13} \mathrm{C}(\mathrm{d} 13 \mathrm{C})$ and C/S ratio. 
According to Delavy et al. (2016), the organic matter quality in the NE region of Guanabara Bay is adequate to gas production. The mean $-23.1 \pm 1.5 \% 0 \delta^{13} \mathrm{C}$ values indicate that the origin of organic matter would be mixed between marine and land-derived materials. The obtained mean value of $\delta^{13} \mathrm{C}$ indicates closer marine origin than terrestrial. The rise of $\delta^{13} \mathrm{C}$ values in the external stations of the study area suggests an improvement of organic matter quality due to marine productivity contribution and reduced deposition of terrestrial organic materials.

The positive and significant correlation between TOC and S2 (Appendix 2) agrees with a higher potential of gas production in the areas with highest TOC content (Delavy et al., 2016). In fact, the same authors reported the presence of trapped gas in subsurface layers of the sediments in the region. This gas seems to be produced by biochemical degradation of organic matter that percolated through the sedimentary column to the surface and is probably released into the water column.

The $\mathrm{CaO}$ is strongly and positively correlated with $\mathrm{Sr}$ (Appendix 2) that might be linked with carbonated shells or tests of organisms. The increase in $\mathrm{MnO}$ content might be related to more oxygenated sediments since $\mathrm{Mn}$ is soluble in anoxic phases of the sediment and precipitates in oxic environments or in oxic frontiers (Howe et al., 2004; Luther III et al., 2011).

The areas, where the sediments are better oxygenated, seem to be more favorable for the development of denser populations with carbonated shells or tests such as mollusks, ostracoda and foraminifera, as indicated by the positive correlation between $\mathrm{CaO}, \mathrm{FD}$ and $\mathrm{MnO}$ (Appendix 2). The PCA analyses (Figs. 7 and 8) evidence that the increase of $\mathrm{Pb}, \mathrm{Zn}, \mathrm{Cu}, \mathrm{Cr}$ is in opposition to the rise of $\mathrm{Al}_{2} \mathrm{O}_{3}, \mathrm{P}_{2} \mathrm{O}_{5}$, $\mathrm{SO}_{3}, \mathrm{Fe}_{2} \mathrm{O}_{3}, \mathrm{MgO}$ and $\mathrm{C} / \mathrm{S}$. This trend indicates that these metals' enrichments occur in reduced phases of the sediments and should be associated with sulphides.

Concentrations of these metals in most of the sites can be considered relatively low when compared with other regions of Guanabara Bay (e.g., Baptista Neto et al. 2000, 2005, 2006; Faria and Sanchez, 2001; Covelli et al., 2012; Donnici et al., 2012; Cordeiro et al., 2015). According to the results of these authors, the studied area can be considered one of the least polluted parts by metals of Guanabara Bay. However, an enrichment of $\mathrm{Pb}, \mathrm{Zn}, \mathrm{Cu}$ and $\mathrm{Cr}$ was observed near the São Gonçalo city region. Metal concentrations decrease to northeast due to the runoff of unpolluted rivers and the occurrence of the mangrove systems of the Apa of Guapimirim, an environmental protected area (Baptista Neto et al., 2006).

\subsection{The response of total living benthic foraminiferal assemblages to eutrophication and metals contamination}

Total living benthic foraminiferal assemblages recognized in the NE sector of GB are characterized by low abundance, diversity and equitability that might indicate that this sector of the bay displays high environmental stress. The main species of benthic foraminifera and FD, J' and $\mathrm{H}^{\prime}$ identified in the $\mathrm{NE}$ region of $\mathrm{GB}$ are in general poorly correlated with metals enrichment (Appendix 2), except $A$. tepida (with significant negative correlations with all metals) and $\mathrm{R}$. nana (with significant negative correlations with $\mathrm{Cr}$ and $\mathrm{Zn}$ ). Ammonia tepida is positively correlated with TOC, $\mathrm{Al}_{2} \mathrm{O}_{3}, \mathrm{MgO}$ and $\mathrm{S} 2$ that might evidence that this species populates mostly areas where organic matter is in an oxidized state; and is probably tolerant to potential gas seepages. A similar situation occurs with $R$. nana and $C$. excavatum as suggested by the statistic results (see Groups I of PCA included in Fig. 8 and Appendix 2). These species seem to tolerate high degree of disturbance caused by eutrophication and by rivers outflow.

In contrast, $\mathrm{FD}, \mathrm{H}^{\prime}$ and $\mathrm{J}$ ' values and the relative abundance of species such as B. elegantissima, B. striatula, E. gerthi, and $G$. praegeri as well as $A$. tepida and $\mathrm{R}$. nana are positively related to $\mathrm{MnO}, \mathrm{CaO}$ and $\delta^{13} \mathrm{C}$ values (Group III of PCA included in Fig. 7). The combination of these variables indicates that foraminifera are benefited by less eutrophic conditions, more oxygenated and high quality organic matter (essentially of marine origin) environments.

In general, species such as B. elegantissima, B. striatula, E. gerthi, and G. praegeri are much more typical of oceanic environments than from transitional coastal ecosystems (Murray 1991, 2006). Thus, the presence of these species seems to track the stations with highest marine influence in the NE sector of Guanabara Bay.

\subsection{Factors controlling the size of living benthic foraminifera}

Results presented in Appendix 3 evidence that the relative abundances of the living specimens identified in the 63-150 $\mu \mathrm{m}$ sedimentary fraction (FFF) and in the 150-250 $\mu \mathrm{m}$ sediment fraction (FMF) of $A$. tepida, B. elegantissima, $B$. striatula, R. nana, E. gerthi, B. lowmani, T. inflata are positively correlated. Only some species reach dimensions $>250 \mu \mathrm{m}$ (FCF) in some stations, such as A. tepida, C. excavatum, $B$. elegantissima, some bolivinids and buliminids in station GB1. The FD, H' and J' and A. tepida, B. elegantissima, B. striatula, E. gerthi, T. inflata and G. praegeri in both FFF and FMF are positively associated with the Factor 2 of the PCA of Figure 8 jointly with $\mathrm{MnO}, \mathrm{CaO}, \mathrm{Sr}$ and $\delta^{13} \mathrm{C}$ (Fig. 8; Group III). 
The $\delta^{13} \mathrm{C}$ values have significant positive correlations with the FD, H', J' and B. striatula in 63-150 $\mu \mathrm{m}$ sediment fraction as well as E. gerthi and B. striatula in 150-250 $\mu \mathrm{m}$ sediment fraction (Appendix 2). These results suggest that several species of FFF in the NE sector of GB mostly populate areas with organic matter related mostly to marine productivity.

Bolivina striatula as well as E. gerthi are probably the most demanding species by organic matter quality in the study area. Both species mainly populate oceanic settings (Murray, 2006) so they trace the highest marine influence in GB. Ammonia tepida is known by its versatile and diversified diet (Pierre-Yves et al., 2008; Dupuy et al., 2010). This species can feed on vegetal detritus, microalgae and bacteria and can capture small preys (Pierre-Yves et al., 2008; Dupuy et al., 2010).

The FD, H', J' of the in 63-150 $\mu$ m sediment fraction (FF) as well as FD of $150-250 \mu \mathrm{m}$ sediment fraction (MF) also have significant positive correlations with $\mathrm{MnO}$, which is indicative a generic preference by oxygenated sedimentary environment, namely of $A$. tepida, B. elegantissima. E. gerthi, $G$. praegeri, T. inflata and B. striatula.

The relative abundance of $A$. tepida and $\mathrm{R}$. nana in $\mathrm{FF}$ and $\mathrm{MF}$ are positively related to the Factor 1 of the PCA of Figure 8 (Group I) in conjunction with $\mathrm{C} / \mathrm{S}$, TOC, S2, fine fraction, $\mathrm{SO}_{3}, \mathrm{Al}_{2} \mathrm{O}_{3}, \mathrm{P}_{2} \mathrm{O}_{5}, \mathrm{MgO}$ and $\mathrm{Fe}_{2} \mathrm{O}_{3}$. These results suggest that these species might be able to live and grow in the areas of the NE sector of Guanabara Bay, where the sediment is enriched in organic matter in an oxidizing state.

A similar situation is observed for the juveniles of $R$. nana, C. excavatum and B. lowmani. Whereas A. tepida and R. nana may tolerate the organic enrichment in areas where organic matter is being oxidized and gas escape should occur, some species such as $C$. excavatum and B. lowmani can live in those impacted conditions but their growth may be more limited.

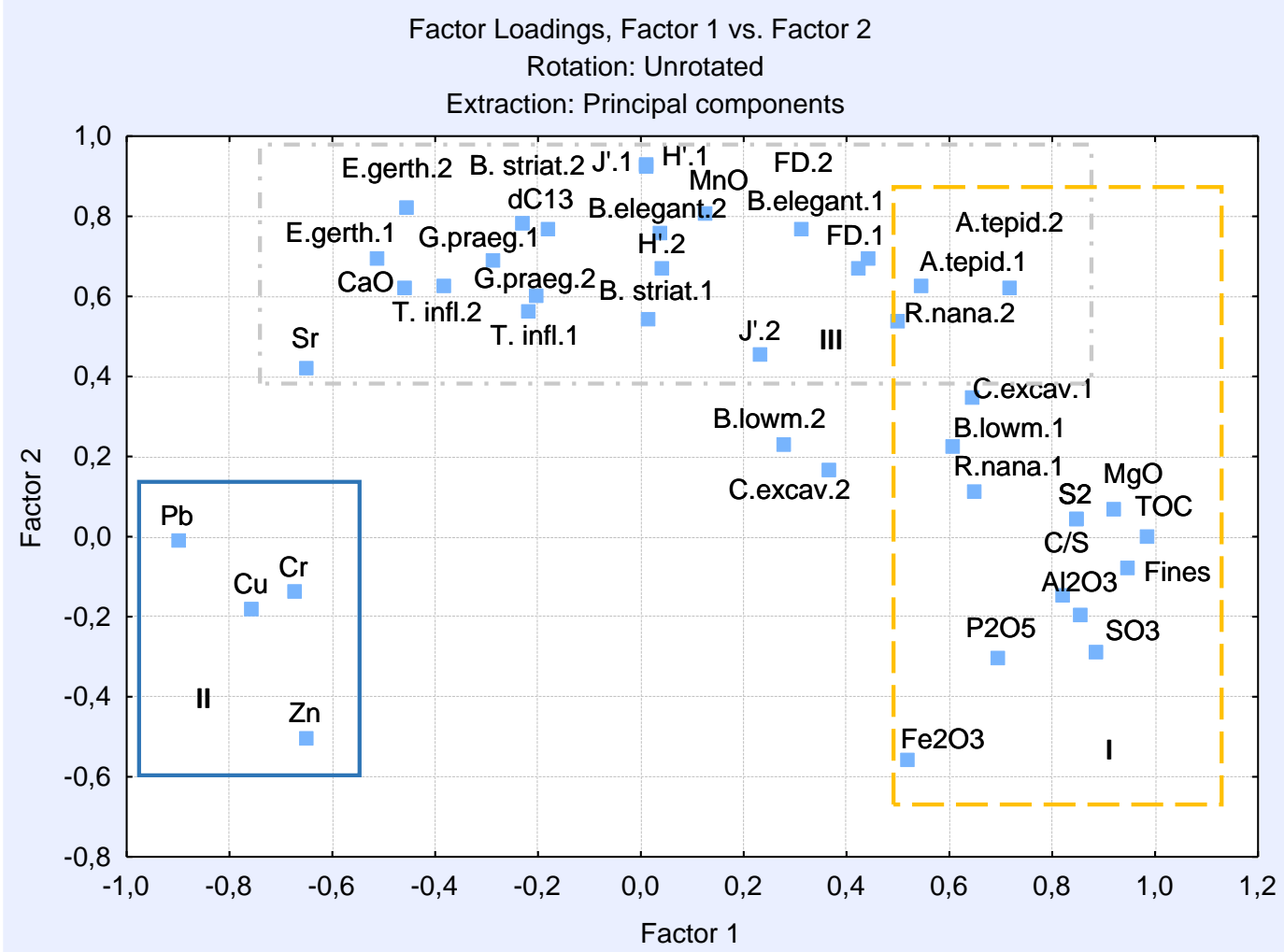

Fig. 8. Principal Component Analysis based on: concentrations of $\mathrm{Cr}, \mathrm{Cu}, \mathrm{Pb}, \mathrm{Zn}, \mathrm{Sr}, \mathrm{Al}_{2} \mathrm{O}_{3}\left(\mathrm{Al}_{3} \mathrm{O}_{3}\right), \mathrm{P}_{2} \mathrm{O}_{5}\left(\mathrm{P}_{2} \mathrm{O}_{5}\right), \mathrm{SO}_{3}(\mathrm{SO} 3), \mathrm{Fe}_{2} \mathrm{O}_{3}$ (Fe2O3), $\mathrm{CaO}$ and $\mathrm{MnO}$; percentage of fine fraction (Fines), TOC, A. tepida (A.tepid.), C. excavatum (C.excav.), R. nana, B. lowmani (B.lowm.), B. elegantissima (B.elegant.), B. striatula (B. striat.), E. gerthi (E.gerth.), G. praegeri (G.praeg.) and T. inflata (T.infl.). Foraminiferal density (FD), Shannon index (H'), equitability (J'), S2 and $\delta^{13} \mathrm{C}(\mathrm{d} 13 \mathrm{C})$ were also considered. The number associated with the species and assemblages parameters is related to sediment fractions: 1 for $63-150 \mu \mathrm{m}$ and 2 for $150-250 \mu \mathrm{m}$. Species and assemblages parameters in the 250-500 $\mu \mathrm{m}$ sediment fraction were not considered due to the reduced number or absence of living specimens. 
According to the results presented in Appendix 2, the percentage of specimens of $A$. tepida and $\mathrm{R}$. nana in $\mathrm{FF}$ and $\mathrm{MF}$ has negative correlations with $\mathrm{Cr}, \mathrm{Cu}, \mathrm{Pb}$ and $\mathrm{Zn}$. The percentage of specimens of $C$. excavatum in $\mathrm{FF}$ is also negatively correlated with $\mathrm{Cr}, \mathrm{Cu}$ and $\mathrm{Zn}$. These metals are negatively related to the Factor 1 of the PCA presented in both Figures 7 and 8 and are in opposition to the sedimentary oxides (such as $\mathrm{SO}_{3}, \mathrm{Al}_{2} \mathrm{O}_{3}, \mathrm{P}_{2} \mathrm{O}_{5}, \mathrm{MgO}$ and $\left.\mathrm{Fe}_{2} \mathrm{O}_{3}\right)$.

These results may indicate that metals retention in the sediments of the NE region of GB should mainly occur in sedimentary reducing phases and probably associated with sulfides production, such as pyrite, which is common in sediments rich in organic matter in transitional environments (Martins et al., 2015, 2016a, b).

Ammonia tepida and R. nana (Group I of PCA of Fig. 8) can populate and grow in sediments rich in organic matter, but they are probably affected by deeply reducing conditions associated with an increasing of metals concentrations retained in reducing phases of the sediments. These species can grow $(<250 \mu \mathrm{m})$ in stations displaying aerated sediments, relatively low metals and TOC contents retained in reduced sedimentary phases and available organic matter of high quality.

The juveniles of C. excavatum and B. lowmani (Group I of PCA of Fig. 8) also seem to be able to populate areas with high degree of eutrophication where the organic matter is under oxidizing conditions and metals concentrations are low but, in general, they are only limited to FF $(63-150 \mu \mathrm{m})$. Bolivina lowmani is an oceanic species and thus low salinities near the rivers mouths should be a limiting factor for its growth.

The results of this study show that in the majority of the stations benthic foraminifera do not reach large sizes. The living assemblages include mostly specimens with small dimensions between 63-250 $\mu \mathrm{m}$.

Living benthic foraminifera were rare in GB8 station and the FD was also low in the GB9 station. These stations were the most polluted by metals and probably have high content of organic matter of low quality (in reduced sedimentary phases).

No FFF were found in station GB9 but only FMF (150$250 \mu \mathrm{m})$. On the other hand, a significant number of bolivinids and buliminids including B. compacta, B. lowmani, $B$. striatula, B. aculeata, B. gibba and B. marginata (not including Buliminella elegantissima) reached relatively high percentage (up to $18 \%$ ) in stations GB5-GB7 and GB1, mostly in sediment fraction 63-150 $\mu \mathrm{m}$ (Fig. 6D). These species of bolivinids and buliminids are typical of oceanic settings.

Bolivinids and buliminids have been considered opportunistic species and are, in general, well represented in areas that receive high and sustainable flux of organic matter (Martins et al., 2007 and references herein). However, the environmental variability should limit the growth of these species in the NE sector of Guanabara Bay. Relatively high percentage of bolivinids and buliminids was found in GB6 $(\approx 11 \%)$ and GB7 $(\approx 3 \%)$ in the sediment fraction $150-250$ $\mu \mathrm{m}$, which should indicate a relatively high environmental stability to allow the growth of these organisms in these stations in comparison with other study areas.

According to the results of this work, the living foraminiferal assemblages in the studied region denote great environmental stress. The stations where the environmental conditions seem to be most particularly stressed are GB8 and GB9 located close to São Gonçalo city.

\section{Conclusion}

Results obtained in this work evidence that benthic foraminifera can live and reproduce in the $\mathrm{NE}$ region of Guanabara Bay where the sediments have high TOC content. However, their living assemblages reach small dimension and have low diversity and equitability, which suggests stressing environmental conditions in this region.

The most eutrophic zones are populated by a few species and with small size. On the contrary, in less impacted areas by metals and organic matter, foraminiferal assemblages are found in coarse fractions and are more diversified.

Ammonia tepida was the most dominant species in the living assemblages in the NE sector of Guanabara Bay during the sampling event. This species can grow in the most impacted areas by organic matter; however, it has preference by environments where the organic matter is in an oxic stage.

The most adverse places seem to be those where organic matter and metals are retained in reducing phases of the sediment such as in front of São Gonçalo city. 
This work suggests that the analysis of the living foraminiferal dimension and structure might represent a useful methodology to assess the environmental quality in the coastal region.

\section{Acknowledgments}

This work was partially supported by funds from the UID/GEO/04035/2013 (FCT, Portugal). The authors would like to thank the Fundação de Amparo à Pesquisa do Estado do Rio de Janeiro - FAPERJ for partial financial support of LGQM-UERJ and for the fellowship given to Maria Clara Machado da Fonseca. The authors would like to thank Mrs. Carmen Lúcia Alferes, Mr. Nelson José Marques and Mr. Marcos Gonçalves, of LGQMUERJ, for technical support.

Appendices 1-3 are attached as supplementary material (SM1SM3) in http://www.e-

publicacoes.uerj.br/index.php/jse/article/view/26872

\section{References}

Alve, E., 1995. Benthic foraminifera response to estuarine pollution: a review. Journal of Foraminiferal Research 25, 190 203. DOI: $10.2113 /$ gsjfr.25.3.190

Armynot du Châtelet, E., Debenay, J.P., 2010. Anthropogenic impact on the western French coast as revealed by foraminifera: a review. Revue de Micropaléontologie 53, 129137.

Baptista Neto, J.A., Gingele, F.X., Leipe, T., Brehme, I., 2006. Spatial distribution of heavy metals in surficial sediments from Guanabara Bay: Rio de Janeiro, Brazil. Environmental Geology 49, 1051-1063. DOI: 10.1007/s00254-005-0149-1

Baptista Neto, J.A., Crapez, M., McAlister, J.J., Vilela, C.G.G., 2005. Concentration and bioavailability of heavy metals in sediments from Niteroi Harbour (Guanabara Bay/S.E. Brazil). Journal of Coastal Research 21, 811-817. doi: http://dx.doi.org/10.2112/012-NIS.1

Baptista Neto, J.A., Smith, B.J., Mcalliste, J.J., 2000. Heavy metal concentrations in surface sediments in a nearshore environment, Jurujuba Sound, SE Brazil. Environmental Pollution 109 (1), 1-9. doi.org/10.1016/S0269-7491(99)00233$\mathrm{X}$

Barrocas, P.R., Wasserman, J.C., 1993. O mercúrio na Baía de Guanabara: uma revisão histórica. Programa de PósGraduação em Geoquímica, UFF, Niterói, RJ, p. 115-127.

Borrego, J., Lopez, M., Pedon, J.G., Morales, J.A., 1998. C/S ratio in estuarine sediments of the Odiel River to mouth, S.W. Spain. Journal of Coastal Research 14(4), 1276-1283.
Clemente, I.M.M.M., Silva, F.S., Laut, L.L.M., Frontalini, F., Costa, V.L., Rodrigues, M.A.C., Pereira, E., Bergamaschi, S., Filho, J.G.M., Martins, M.V.A., 2015. Biochemical Composition and Foraminiferal Content of Sediments for Determining Bottom Sector Environments in Guanabara Bay (Rio de Janeiro, Brazil). Journal of Coastal Research 315, 1190-1204. doi.org/10.2112/JCOASTRES-D-14-00104.1

Cordeiro, R.C., Machado, W., Santelli, R.E., Figueiredo, A.G., Seoane, J.C.S., Oliveira, E.P., Freire, A.S., Bidone, E.D., Monteiro, F.F., Silva, F.T., Meniconi, M.F.G., 2015. Geochemical fractionation of metals and semimetals in surface sediments from tropical impacted estuary (Guanabara Bay, Brazil). Environmental Earth Sciences 74, 1363-1378. DOI: 10.1007/s12665-015-4127-y

Covelli, S., Protopsalti, I., Acquavita, A., Sperle, M., Bonardi, M., Emili, A., 2012. Spatial variation, speciation and sedimentary records of mercury in the Guanabara Bay (Rio de Janeiro, Brazil). Continental Shelf Research 35, 29-42. doi.org/10.1016/j.csr.2011.12.003

Delavy, F.P., Figueiredo Jr., A.G., Martins, M.V.A., Rodrigues, R., Egberto Pereira, Brito, M.A.R.C., Fonseca, M.C.M., Laut, L.L.M., Bergamaschi, S., Miranda, P., Rodrigues, M.A.C., 2016. High-resolution acoustic mapping of gas charged sediments and living benthic foraminifera assemblages from the ne region of Guanabara Bay, Rj, Brazil. Journal of Sedimentary Environments 1 (3), 367-392. doi: 10.12957/jse.2016.26281

Donnici, S., Serandrei-Barbero, R., Bonardi, M., Sperle, M., 2012. Benthic foraminifera as proxies of pollution: The case of Guanabara Bay (Brazil). Marine Pollution Bulletin 64, 20152028. doi: 10.1016/j.marpolbul.2012.06.024.

Dupuy, C., Rossignol, L., Geslin, E., Pascal, P-Y., 2010. Predation of mudflat meio-macrofaunal metazoansby a calcareous foraminifer, Ammonia tepida (Cushman, 1926). Journal of Foraminiferal Research 40, 305-312.

Eichler, P.P.B., Eichler, B.B., Miranda, L.B., Pereira, E.R.M., Kfouri, P.B.P., Pimenta, F.M., Bérgamo, A.L., Vilela, C.G., 2003. Benthic foraminiferal response to variations in temperature, salinity, dissolved oxygen and organic carbon, in the Guanabara Bay, Rio de Janeiro, Brazil. Anuário do Instituto de Geociências - UFRJ 26, 36-51.

Espitalié, J., Laporte, J.L., Madec, M., Marquis, F., Leplat, P., Paulet, J., Boutefeu, A., 1977. Methode rapide de caracterisation des roches meres, de leur potential petrolier et de leur degre d'evolution. Revue de l'Institut Francais du Petrole 32, 23-42.

Faria de Melo, M., Sanchez, B.A., 2001. Geochemistry and mineralogy of recent sediments of Guanabara Bay (NE sector) and its major rivers - Rio de Janeiro State - Brazil. Anais da Academia Brasileira de Ciências 73, 121-133.

Fontana, L.F., Laut, L.L.M., Figueiredo Jr., A.G., Crapez, M.A.C., Rosa, T.D.L., 2006. Foraminifera and bacterial activity in oil spill impacted mangrove, Guanabara Bay, Brazil. Anuário do Instituto de Geociências-UFRJ 29(1), 415-416. 
Frontalini, F., Coccioni, R., 2011. Benthic foraminifera as bioindicators of pollution: A review of Italian research over the last three decades. Revue de Micropaléontologie 54, 115-127.

Frontalini F., Buosi C., Da Pelo S., Coccioni R., Cherchi A., Bucci C., 2009. Benthic foraminifera as bio-indicators of trace element pollution in the heavily contaminated Santa Gilla lagoon (Cagliari, Italy). Marine Pollution Bulletin, 58, 858-877. doi.org/10.1016/j.revmic.2011.03.001

Guimarães, G.P., Mello, W.Z., 2006. Estimativa do fluxo de amonia na interface ar-mar na Baia de Guanabara-estudo preliminar. Química Nova 29(1), 54.

Howe, P.D. Malcolm, H.M., Dobson, S., 2004. Manganese and its compounds: environmental aspects. World Health Organization. International Programme on Chemical Safety. http://www.who.int/iris/handle/10665/42992

Kfouri-Cardoso, P.B.P., Simões, M.G., Rodrigues, S.C., Eichler, B.B., Sousa, S.H.M., Eichler, P.B., Figueira, R.C.L., 2006. Taphonomy of benthic foraminiferal tests from the Jurujuba Sound, Guanabara Bay, Rio de Janeiro, Brazil. Anuário do Instituto de Geociencias-UFRJ 29 (1), 546-547.

Kjerfve, B., Ribeiro, C.H.A., Dias, J.T.M., Filippo, A.M., Quaresma, V.S., 1997. Oceanographic characteristics of an impacted coastal bay: Baía de Guanabara, Rio de Janeiro, Brazil. Continental Shelf Research 17 (13), 1609-1643. doi:10.1016/S0278-4343(97)00028-9

Laut, L.L.M., Clemente, I.M.M.M., Belart, P., Martins, M.V.A., Frontalini, F., Laut, V.M., Gomes, A., Boski, T., Lorini, M.L., Fortes, R.R., Rodrigues, M.A.C., 2016. Multiproxies (benthic foraminifera, ostracods and biopolymers) approach applied to identify the environmental partitioning of the Guadiana River Estuary (Iberian Peninsula). Journal of Sedimentary Environments 1(2): 184-201. doi: 10.12957/jse.2016.22534

Leal, M., Wagener, A., 1993. Remobilization of anthropogenic copper deposited in sediments of a tropical estuary. Chemical Speciation Bioavailability 24(1), 31-39.

Luther III, G.W., Findlay, A.J., Macdonald, D.J., Owings, S.M., Hanson, T.E., Beinart, R.A., Girguis, P.R., 2011.Thermodynamics and Kinetics of Sulfide Oxidation by Oxygen: A Look at Inorganically Controlled Reactions and Biologically Mediated Processes in the Environment. Frontiers in Microbiology 2, 62. doi: 10.3389/fmicb.2011.00062.

Martins, M.V.A., Hohenegger, J., Frontalini, F., Paulo Miranda,P., Rodrigues, M.A.C.R., Alveirinho Dias, J. M., $2016 \mathrm{a}$. Comparison between the dead and living benthic foraminiferal assemblages in Aveiro Lagoon (Portugal). Palaeogeography, Palaeoclimatology, Palaeoecology 455 (1), 16-32. doi: 10.1016/j.palaeo.2016.05.003

Martins, M.V.A., Helali, M. A., Zaaboub, N., Boukef-BenOmrane, I., Frontalini, F., Reis, D., Portela, H., Clemente, I.M.M.M., Nogueira, L., Pereira, E., Miranda, P., El Bour, M., Aleya, L., 2016b. Organic matter quantity and quality, metals availability and foraminifera assemblages as environmental proxy applied to the Bizerte Lagoon (Tunisia). Marine Pollution Bulletin 105, 161-179. doi.org/10.1016/j.marpolbul.2016.02.032.

Martins, M.V.A. Zaaboub, N., Aleya, L., Frontalini, F., Pareira, E., Miranda, P., Mane, M., Rocha, F., Laut, L., El Bour, M., 2015. Environmental quality assessment of Bizerte Lagoon (Tunisia) using living foraminifera assemblages and a multiproxy approach. PLoS ONE. doi.10.1371/journal.pone.0137250

Martins, V., Dubert, J., Jouanneau, J-M., Weber, O., Silva, E.F., Patinha, C., Alveirinho Dias, J.M., Rocha, F., 2007. A multiproxy approach of the Holocene evolution of shelf-slope circulation on the NW Iberian Continental Shelf. Marine Geology 239, 1-18. doi.org/10.1016/j.margeo.2006.11.001

Murray, J.W., 1991. Ecology and Palaeoecology of Benthic Foraminifera New York: Longman Scientific and Technical 402p.

Murray, J.W., 2006. Ecology and applications of benthic foraminifera, Cambridge, UK, Cambridge University Press, 426p.

Perin, G., Fabris, R., Manente, S., Rebello Wagener, A., Hamacher, C., Scotto, S., 1997. A five-year study on the heavy-metal pollution of Guanabara Bay sediments (Rio de Janeiro, Brazil) and evaluation of the metal bioavailability by means of geochemical. Water Research 31(12), 3017-3028.

Pierre-Yves P, Dupuy C, Richard P, Niquil N., 2008. Bacterivory in the common foraminifer Ammonia tepida: Isotope tracer experiment and the controlling factors. Journal of Experimental Marine Biology and Ecology 359, 55-61.doi 10.1016/j.jembe.2008.02.018

Rebello, A.L., Haekel, W., Moreira, I., Santelli, R., Schroeder, F., 1986. The fate of heavy metals in an estuarine tropical system. Marine Chemistry 18, 215-225.

Schönfeld, J., Alve, E., Geslin, E., Jorissen, F., Korsun, S., Spezzaferri, S. and members of the FOBIMO group, 2012. The FOBIMO (FOraminiferal BIo-MOnitoring) initiative Towards a standardised protocol for soft-bottom benthic foraminiferal monitoring studies. Marine Micropaleontology 94-95, 1-13. doi.org/10.1016/j.marmicro.2012.06.001

Stein, R., 1991. Accumulation of organic carbon in marine sediments. Results from the Deep Sea Drilling Project/Ocean Drilling Program. In: Bhattacharji, S., Friedman, G. M., Neugebauer, H.J., Seilacher, A. Lecture Notes in Earth Sciences. Berlin: Springer, 217 p.

Vandenberg, C., Rebello, A.L., 1986. Organic copper interactions in Guanabara Bay, Brazil - an electrochemical study of copper complexation by dissolved organic material in a tropical bay. Science of Total Environment 58 (1-2), 37-45.

Vilela, C.G., Figueira, B.O., Macedo, M.C., Baptista Neto, J.A., 2014. Late Holocene evolution and increasing pollution in Guanabara Bay, Rio de Janeiro, SE Brazil. Marine Pollution Bulletin 79, 175-187. doi: 10.1016/j.marpolbul.2013.12.020 
Vilela, C.G., Batista, D.S., Baptista Neto, J.A., Ghiselli, R.O., 2011. Benthic foraminifera distribution in a tourist lagoon in Rio de Janeiro, Brazil: A response to anthropogenic impacts. Marine Pollution Bulletin 62, 2055-2074. doi.org/10.1016/j.marpolbul.2011.07.023

Vilela, C.G., Figueira, B.O., Baptista Neto, J.A., 2007. Ecologia e Paleocologia na Baía de Guanabara, Rio de Janeiro, Durante os Últimos 6000 anos, com Base em Variações na Assembléia de Foraminíferos Bentônicos. Paleontologia: Cenários da Vida. Editora Interciência 2, 345-361.
Vilela, C.G., Batista, D.S., Baptista-Neto, J.A., Crapez, M., Mcallister, J.J., 2004. Benthic foraminifera distribution in high polluted sediments from Niterói Harbor (Guanabara Bay), Rio de Janeiro, Brazil. Anais da Academia Brasileira de Ciências 76, 161-171.

Yamashita, C., Nagai, R.N., Martins, M.V.A., Vicente, T.M., Sousa, S.H.M., Frontalini, F., Palóczy, A., Mahiques, M.M., Godoi, S.S., MontoyaMontes, I., Figueira, R.C.L., 2016. On the interplay between hydrodynamics, bottom morphology, sedimentary processes and benthic foraminifera assemblages in the São Paulo Bight (Brazil, SW Atlantic). Journal of Sedimentary Environments 1(3): 334-355. doi: 10.12957 /jse.2016.25990 